REVIEW ARTICLE

\title{
Birds and hard ticks (Acari: Ixodidae), with discussions about hypotheses on tick evolution
}

\author{
Guglielmone $A A^{1,2}$, Nava $S^{1,2, *}$ \\ ${ }^{1}$ Instituto Nacional de Tecnología Agropecuaria, Estación Experimental Agropecuaria Rafaela, Argentina \\ ${ }^{2}$ Consejo Nacional de Investigaciones Científicas y Técnicas, Argentina \\ * Correspondence: Santiago Nava, INTA EEA Rafaela, CC 22, CP 2300 Rafaela, Santa Fe, Argentina. \\ E-mail: nava.santiago@inta.gob.ar
}

Received: 3 March 2017. Accepted: 11 June 2017. Available online: 22 June 2017

Editor: P.M. Beldomenico

\begin{abstract}
SUMMARY. The relationship between birds (Aves) and hard ticks (Ixodidae) was analyzed for the 386 of 725 tick extant species whose larva, nymph and adults are known as well as their natural hosts. A total of 136 (54 Prostriata= Ixodes, 82 Metastriata= all other genera) are frequently found on Aves, but only 32 species ( 1 associated with Palaeognathae, 31 with Neognathae) have all parasitic stages feeding on birds: 25 Ixodes (19\% of the species analyzed for this genus), 6 Haemaphysalis (7\%) and 1 species of Amblyomma (2\%). The species of Amblyomma feeds on marine birds (MB), the six Haemaphysalis are parasites of non-marine birds (NMB), and 14 of the 25 Ixodes feed on NMB, one feeds on NMB and MB, and ten on MB. The Australasian Ixodes +1 . uriae clade probably originated at an uncertain time from the late Triassic to the early Cretaceous. It is speculated that Prostriata first hosts were Gondwanan theropod dinosaurs in an undetermined place before Pangaea break up; alternatively, if ancestral monotromes were involved in its evolution an Australasian origin of Prostriata seems plausible. As for Prostriata the Motherland of Ixodida is probably Gondwana.
\end{abstract}

RESUMEN. Aves y garrapatas duras (Ixodidae), con discusión sobre hipótesis sobre evolución de las garrapatas. En esta revisión se analizó la relación entre aves y garrapatas duras (Ixodidae) para las 386 de 725 especies de garrapatas que utilizan aves como hospedadores para larvas, ninfas y adultos. Un total de 136 especies (54 Prostriata= Ixodes, 82 Metastriata= restantes géneros) son frecuentemente encontradas sobre aves, pero solo 32 especies (1 asociada con Palaeognathae, 31 con Neognathae) tienen ciclos donde todos los estadios se alimentan sobre aves: 25 Ixodes (19\% de las especies analizadas para este género), 6 Haemaphysalis ( $7 \%$ del total) y 1 especie de Amblyomma (2\% del total). Las especies de Amblyomma se alimentan sobre aves marinas (MB), las seis de Haemaphysalis son parásitas de aves no-marinas (NMB), y 14 de las 25 especies de Ixodes se alimentan sobre NMB, una sobre NMB y MB, y diez sobre MB. El clado de Australasia Ixodes + I. uriae probablemente se originó entre el fin del Triásico y comienzos del Cretácico. Se especula que los primeros hospedadores de Prostriata fueron dinosaurios terópodos con distribución Gondwánica; alternativamente, si monotremas ancestrales estuvieron involucrados en su evolución, un origen de Prostriata en Australasia es plausible. Al igual que para Prostriata, el área de origen de Ixodida es probablemente Gondwana.

Key words: Aves, Ixodidae, Prostriata, Metastriata, evolution.

Palabras clave: Aves, Ixodidae, Prostriata, Metastriata, evolución.

\section{Introducción}

Birds (Class Aves) evolved from theropod dinosaurs in the Jurassic period (Mesozoic) with the first fossils dated 165-150 mya. They are the only clade of dinosaurs that survived the Cretaceous-Paleogene boundary (K-Pg boundary) with a strong radiation in the Tertiary along with Mammalia (Chiappe, 2009; Brusatte et al., 2015). The modern Aves (Neornithes) contains about 10,000 extant species covering all the ecosystems on earth (strictly aquatic environments excluded) which are further divided into two clades: the Palaeognathae constituted by about 60 species of flightless birds distributed in the Afrotropical, Australasia and Neotropical Zoogeographic Regions, and the Neognathae formed by almost all extant birds with a worldwide distribution.

Ixodidae (ticks with all postembryonic stages with the dorsum partially or totally covered by a chitinous scutum) currently contains 725 species (Guglielmone and Nava, 2014; Hornok et al., 2016; Apanaskevich and Bermudez, 2017; Ash et al., 2017; Nava et al., 2017) This tick family is divided in two groups: Prostriata, containing the genus Ixodes although French workers divide it into several genera (Camicas and Morel, 1977; Camicas et al., 1998) and Metastriata that contains 11 
extant and two fossil genera (Guglielmone et al., 2014). Hypotheses based on molecular data state that Prostriata probably evolved earlier than Metastriata (Black and Roehrdanz, 1998; Jeyaprakash and Hoy, 2009; Mans et al., 2012) and Australasian species such as Ixodes tasmani Neumann, 1899 and Ixodes holocyclus Neumann, 1899 plus the circumpolar aviandependant Ixodes uriae White, 1852 are claimed to be basal to the rest of the group (Norris et al., 1999; Klompen, 1999; Klompen et al., 2000). The basal position of $I$. uriae has been long recognized, among others, by Zumpt (1952 as Ceratixodes uriae) who stated that this tick is peculiar by having primitive morphology, and Morel (1969 also as C. uriae) asserted that this species was associated to marine birds in the Cretaceous and the genus may have originated in the Jurassic feeding on reptiles.

Fossil evidence shows the earliest emergence of Metastriata including the extant genus Amblyomma 100 mya (Cretaceous) (Grimaldi et al., 2002) while molecular clock placed its origin in the late Jurassicearly Cretaceous Periods (156-112 mya) (Jeyaprakash and Hoy, 2009) and from mid Jurassic-early Cretaceous (166-101 mya) by Mans et al. (2012). There is no Prostriata fossil as old as Metastriata fossil record, but molecular clock indicates the earliest period of its evolution in late Triassic Period (223 mya) and the latest in mid Jurassic Period (169 mya) according to Jeyaprakash and Hoy (2009) and from 266 (Permian) to mid Jurassic (171 mya) in Mans et al. (2012). The origin of Ixodida and their primeval host are also controversial with several competing theories proposed in Jeyaprakash and Hoy (2009), Mans et al. (2011, 2012, 2014, 2016) and Barker et al. (2014), among others, a topic that will be further treated in the discussion about hypotheses of tick evolution.

The evolutionary histories of Aves and Ixodidae may indicate an ancient relationship as hypothesized by Morel (1969), Stothard and Fuerst (1995), Kolonin (2008), Dietrich et al. (2014) and de la Fuente et al. (2015). There are works about Aves as hosts for particular species of ticks, but few give an ample scope on this tick-host relationship. Kolonin (2008) shows the broad relationship as Aves as hosts for adult ixodid ticks, Arthur (1958, 1960) and Dietrich et al. (2011) summarized the distribution of ticks from marine birds, Zumpt (1952) presented data about Ixodidae and sea birds in the Antarctic, while Guglielmone et al. (2014) analyzed the role of Aves for all species of Ixodidae. Here we analyze Aves as hosts for Ixodidae focusing on species whose post embryonic stages (larva, nymph, adult) are strictly related to Aves considering that this information is relevant to understand part of tick life history. Related to this topic we take the opportunity to discuss some aspects of tick evolution from alleged ancient Prostriata ticks feeding on marine birds as well as hypotheses of the origin of ticks.

\section{Materials and methods}

Basic information for this study was obtained from Guglielmone et al. (2014), who analyzed host profiles of 378 species of Ixodidae whose adults, nymphs and larvae are known as well as their natural hosts plus new information for a total of 386 species (133 Prostriata, 253 Metastriata). The genera with new information on this topic are Amblyomma after the studies of Apanaskevich et al. (2016) with Amblyomma integrum Karsch, 1879 and Muñoz-Leal et al. (2016) with Amblyomma parvitarsum Neumann, 1901, and Dermacentor based on the studies of Apanaskevich (2013), Apanaskevich and Bermúdez (2013), Apanaskevich et al. (2014) and Apanaskevich and Apanaskevich $(2015,2016)$. Many of these species have been found on Aves, 68 species of Ixodes (67 in Guglielmone et al., 2014 plus Ixodes asanumai Kitaoka, 1973 in Takano et al., 2014), and 152 of Metastriata (147 in Guglielmone et al., 2014 plus Amblyomma auricularium (Conil, 1878) in Lugarini et al., 2015, A. integrum in Apanaskevich et al. 2016, Amblyomma rotundatum Koch, 1844 in Scott and Durden, 2015, Amblyomma varium Koch, 1884 in Lugarini et al. (2015) and Dermacentor bellulus (Schulze, 1935) in Apanaskevich and Apanaskevich, 2015). These numbers diminished to 54 for Prostriata and 82 for Metastriata, when exceptional avian host records are excluded from the analysis. Finally, those numbers are further reduced to 32 (Prostriata + Metastriata) when considered only the species with all parasitic stages bound to Aves.

The 32 species strictly dependent on birds for the maintenance of all parasitic stages are considered relevant for life history of Ixodidae and treated in detail below. The remainder 108 species (Prostriata + Metastriata) are found on Aves and Mammalia (88 species), and the rest on Aves and other types of hosts (data not shown). Some species (i.e. Amblyomma longirostre (Koch, 1844), Amblyomma nodosum Neumann, 1899) use Aves as source of nourishment for larvae and nymphs (Guglielmone et al., 2014; Lugarini et al., 2015; Maturano et al., 2015; Ramos et al., 2015), while larvae and nymphs of species as Ixodes scapularis Say, 1821 are frequently found on Passeriformes but most commonly on small mammals (Keirans et al., 1996) being uncertain if Aves are crucial for its life cycle. It is quite probable that Aves are vital for the cycle of many of the more than 100 species cited above, but the host parasite relationships of tickAves + Mammalia or other types of hosts are treated as a Cenozoic event alongside the radiation of Aves 
and Mammalia after the K-Pg boundary and will not be further discussed.

We focused on the 32 species of Ixodidae that use Aves as a vital source for the nourishment of all parasitic stages according to Guglielmone et al. (2014) plus the addition of Haemaphysalis wellingtoni Nuttall and Warburton, 1908 following Hoogstraal et al. (1972) and Rajagopalan (1972). For each of these species the orders and families of hosts and zoogeographical tick distribution are listed. Orders of avian hosts parasitized by these species were additionally classified as marine (MB) and non-marine birds (NMB). Some of these avian orders have MB and NMB species but the categorization follows the habits of parasitized species (data not shown). Orders and families of birds followed mainly Clements et al. (2012) and are similar but not identical to orders and families used in Guglielmone et al. (2014).

Tick distribution in the Afrotropical (=Ethiopian, African), Australasian, Nearctic, Neotropical, Oriental (= Indomalaya) and Palearctic Zoogeographic Regions were obtained following Cox and Moore (2005) as detailed in Guglielmone et al. (2014). Some species are established in Islands difficult to be associated to any of the regions above mentioned (these islands should be related to Oceanic Region of some authors). In these cases the oceans for island location are named. One species is mainly found around the Poles, but also in islands and continental territories close to them and this distribution is defined as circumpolar.

The information is related to theories of tick evolution focusing on the clade of Australasian Ixodes + uriae (also named as "Australian Ixodes", "Australasian Ixodes" or "Ixodes tasmani group" by others) and related species with notes on evolutionary events occurring before and after the hypothetical origin of this tick clade.

\section{Results}

The vast majority of the 32 species whose all parasitic stages feed on Aves are Prostriata; only 2 of the 11 extant genera of Metastriata have species with larvae, nymphs and adult ticks feeding on Aves for a total of 7 species, 1 Amblyomma and 6 Haemaphysalis. The species of Ixodidae with all parasitic stages feeding on Aves, their distribution, hosts and comments are listed below.

\section{METASTRIATA}

Amblyomma loculosum Neumann, 1907: this species is mainly found on islands close to the Afrotropical, Australasian and Oriental Zoogeographic Regions. All parasitic stages feed on Charadriiformes: Fregatidae and Sulidae; nymphs and adult ticks were recovered from Charadriiformes: Laridae and Procellariiformes: Procellariidae. Dietrich et al. (2011) stated that $A$. loculosum is occasionally found on NMB. All parasitic stages have been found on Squamata: Scincidae which appear to be important hosts for A. loculosum larvae, but the absence of skinks do not imperil the cycle of this tick; therefore, we still consider this tick as bound to MB. Amblyomma loculosum has been exceptionally found on Artiodactyla: Bovidae and also on humans. Main references: Hoogstraal et al. (1976), Ramos et al. (2002), Dietrich et al. (2011), Guglielmone et al. (2014).

Haemaphysalis chordeilis (Packard, 1869): a Nearctic species with all parasitic stages found on Galliformes: Phasianidae and Passeriformes: Icteridae; adult ticks has been found on Anseriformes: Anatidae and Caprimulgiformes: Caprimulgidae, and larvae and nymphs on several families of Passeriformes. Nymphs were also recovered from Accipitriformes: Accipitridae. There are also some unusual records of $H$. chordeilis adults on mammals including humans. Main references: Bequaert (1945), Bishopp and Trembley (1945), Cooley (1946), Gregson (1956), Keirans (1967, 1985), Wilson and Kale (1972), Guglielmone et al. (2014).

Haemaphysalis doenitzi Warburton and Nuttall, 1909: an Australasian-Oriental-Palearctic species. The usual hosts for larvae, nymphs and adult ticks are Cuculiformes: Cuculidae and Galliformes: Phasianidae, but the avian host range is ample. All parasitic stages of $H$. doenitzi have been found on several families of Passeriformes; adults and nymphs on Accipitriformes: Accipitridae, Falconiformes: Falconidae, and Strigiformes: Strigidae, just adult ticks on Coraciiformes: Coraciidae, Upupidae, and Gruiformes: Rallidae; and nymphs on Piciformes: Capitonidae. There are also some exceptional records on mammals (including humans) and reptilian (Testudines). Main references: Hoogstraal and Wassef (1973), Tanskul et al. (1983), Guglielmone et al. (2014).

Haemaphysalis hoodi Warburton and Nuttall, 1909: an Afrotropical species, whose all parasitic stages have been found on Cuculiformes: Cuculidae, Galliformes: Phasianidae and Passeriformes: Muscicapidae; adults and nymphs on Galliformes: Numididae and Passeriformes: Laniidae, and just adult ticks on Accipitriformes: Accipitridae, Ciconiiformes: Ciconiidae, Coraciiformes: Bucorvidae, Cuculiformes: Musophagidae, Falconiformes: Falconidae, Gruiformes: Rallidae and Passeriformes: Corvidae. Nymphs and/or larvae of $\mathrm{H}$. hoodi have been recovered from Columbiformes and Passeriformes. There are also some unusual records of $H$. hoodi from mammals. Main references: Santos Dias (1958), Theiler (1962), Elb and Anastos (1966), Aeschlimann (1967), Matthysse and Colbo (1987), Cornet (1995), Horak et al. (1995), Guglielmone et al. (2014). 
Haemaphysalis megalaimae Rajagopalan, 1963: an Oriental species with all parasitic stages feeding on Piciformes: Capitonidae (Rajagopalan 1963; Guglielmone et al. 2014).

Haemaphysalis minuta Kohls, 1950: an Oriental species whose parasitic stages usually feed on Galliformes: Phasianidae with nymphal records from several families of Passeriformes as well as from Cuculiformes: Cuculidae. There is also a record of larvae of $\mathrm{H}$. minuta on Passeriformes: Timaliidae, and some exceptional records from mammals. Main references: Rajagopalan et al. (1968), Rajagopalan (1972), Rao et al. (1973), Hoogstraal and Kim (1985), Guglielmone et al. (2014).

Haemaphysalis wellingtoni: an Australasian-Oriental species with larvae, nymphs and adults usually feeding on Galliformes: Phasianidae but also recovered from Cuculiformes: Cuculidae and Passeriformes (five families). Additionally larvae, nymphs or adult ticks were found on Accipitriformes: Accipitridae, Charadriiformes: Charadriidae, Coraciiformes: Bucerotidae, Gruiformes: Rallidae and ten families of Passeriformes. There are also records of $H$. wellingntoni from five orders of mammals plus humans. Guglielmone et al. (2014) did not classify $H$. wellingtoni as a species that feed exclusively on Aves after the exclusion of exceptional hosts but this criterion is not applied here. Main references: Trapido et al. (1964), Boshell and Rajagopalan (1968), Hoogstraal et al. (1972), Rajagopalan (1972), Bhat and Sreenivasan (1981), Tanskul et al. (1983), Xu and Li (1997), Parola et al. (2003), Durden et al. (2008), Guglielmone et al. (2014).

\section{PROSTRIATA}

Ixodes anatis Chilton, 1904: an Australasian species with all parasitic stages found on Struthioniformes: Apterygidae, while adults and nymphs have been detected on Anseriformes: Anatidae (Dumbleton 1953, 1961; Heath 2010; Guglielmone et al. 2014; Swift et al. 2015). This bird is the only representative of the clade Palaeognathae from all the 32 species of Ixodidae strictly bound to Aves.

Ixodes arboricola Schulze and Schlottke, 1929: an Oriental-Palearctic species with all parasitic stages found on Passeriformes (seven families), Piciformes: Picidae and Strigiformes: Strigidae. Adult ticks have been recovered from Charadriiformes: Burhinidae and Falconiformes: Falconidae and larvae from Accipitriformes: Accipitridae and Columbiformes: Columbidae, while adults and nymphs of $I$. arboricola have been found on several families of Passeriformes. There are also some exceptional records from Mammalia. Main references: Clifford and Hoogstraal (1965), Gembitsky (1966), Sixl and Nosek (1972), Filippova (1977), Martyn (1988), Jaenson et al. (1994), Yu et al. (1997), Papadopoulos et al.( 2001), Chen et al. (2010), Monerris et al. (2011), Guglielmone et al. (2014).
Ixodes auritulus Neumann, 1904: a species with a wide range including Afrotropical, Australasian, Nearctic and Neotropical Zoogeographic Regions with an ample hosts records from $M B$ and $N M B$ from different orders, with exceptional records from rodents and a mammalian carnivore. All parasitic stages of $l$. auritulus have been found on Falconiformes: Falconidae, Galliformes: Cracidae and Passeriformes (eight families). Larvae, nymphs or adults have been recovered from 11 families of Passeriformes, while nymphs and adult ticks have been found on Columbiformes: Columbidae, Galliformes: Phasianidae, Procellariiformes: Pelecanoididae and Procellariidae, and Tinamiformes: Tinamidae. Nymphs and larvae of $I$. auritulus were determined as parasite of Apodiformes: Apodidae, and adult ticks on Accipitriformes: Accipitridae, Charadriiformes: Stercorariidae, Galliformes: Odontophoridae, Piciformes: Picidae, and Sphenisciformes: Spheniscidae. Undetermined stages of I. auritulus were found on Charadriiformes: Laridae and Scolopacidae, Gruiformes: Rallidae, Procellarriformes: Diomedeidae and Psittaciformes: Strigopidae. Important articles referring to $\mathrm{MB}$ as hosts of $I$. auritulus do not mention tick stages found on them but there is no doubt that there are population of this species bound to MB. Main references: Bequaert (1945), Cooley and Kohls (1945), Arthur (1960), Dumbleton (1961), Roberts (1964), González-Acuña et al. (2005, 2009), Heath (2010), Dietrich et al. (2011), Heath et al. (2011), Guglielmone et al. (2014), Bermúdez et al. (2015), Flores et al. (2014).

Ixodes baergi Cooley and Kohls, 1942: a Nearctic species whose larvae, nymphs and adults have been found on Passeriformes: Hirundinidae, with a record from humans (Keirans et al. 1993; Durden and Keirans 1996; Walker et al. 1998; Guglielmone et al. 2014).

Ixodes berlesei Birula, 1895: a Palearctic species with all parasitic stages usually found on Apodiformes: Apodidae. Larvae and adult ticks were also found on Passeriformes: Emberizidae; nymphs and larvae of $I$. berlesei were recovered from Passeriformes: Corvidae and Passeridae. Undetermined stages of this species were found on Columbiformes: Columbidae; Falconiformes: Falconidae, and several families of Passeriformes. Main references: Emchuk (1960), Chunikhin (1967), Clifford et al. (1975), Filippova (1977), Prokop'ev et al. (1979), Voltzit (1997), Guglielmone et al. (2014).

Ixodes brunneus Koch, 1844: a Nearctic-Neotropical species whose larvae, nymphs and adults usually feed on several families of Passeriformes, but adults and nymphs were also found on Galliformes: Odontophoridae, adult ticks on Piciformes: Rhampastidae and Strigiformes: Strigidae, and larvae on Galliformes: Phasianidae. Undetermined stages of $I$. brunneus have been recovered from Columbiformes: Columbidae, and it was also found on humans. Main references: Bishopp and Trembley (1945), Cooley and Kohls 
(1945), Anastos and Smith (1957), Sonenshine and Stout (1970), Furman and Loomis (1984), Mullen et al. (1999), Williams et al. (1999), Scott et al. (2012), Guglielmone et al. (2014).

Ixodes caledonicus: a Palearctic species with all parasitic stages found on Apodiformes: Apodidae, Columbiformes: Columbidae, Falconiformes: Falconidae and Passeriformes: Corvidae; adult ticks also found on MB (Procellariiformes: Procellariidae). Main references: Filippova (1977), Jaenson et al. (1994), Jaenson and Jensen (2007), Guglielmone et al. (2014).

Ixodes collocaliae Nuttal, 1910: an AustralasianOriental species whose larvae, nymphs and adults have been found on Apodiformes: Apodidae (Wilson 1964b, 1970a; Petney and Keirans 1994; Guglielmone et al. 2014).

Ixodes eudyptidis Maskell, 1885: an Australasian species with all parasitic stages found on Charadriiformes: Laridae and Sphenisciformes: Spheniscidae; nymphs and larvae on Suliformes: Phalacrocoracidae, and nymphs on Suliformes: Sulidae. Undetermined stages of $I$. eudyptidis have been also found on Anseriformes: Anatidae, Charadriiformes: Sternidae and Procellariiformes: Pelecanoididae and Procellariidae. Main references: Dumbleton (1961), Roberts (1960, 1964, 1970), Heath $(2006,2010)$, Heath and Cane (2010), Guglielmone et al. (2014).

Ixodes frontalis (Panzer, 1798): a Palearctic species whose usual hosts for all parasitic stages are Passeriformes: Turdidae, but also recovered from Passeriformes: Acrocephalidae, Muscicapidae and Passeridae. Nymphs of $I$. frontalis were found on Piciformes: Picidae and one or two parasitic stages from 18 families of Passeriformes. There are records of this species from Accipitriformes: Accipitridae, Anseriformes: Anatidae, Charadriiformes: Haematopodidae, Columbiformes: Columbidae, Falconiformes: Falconidae, Galliformes: Phasianidae, Gruiformes: Rallidae and Strigiformes: Strigidae but we were unable to discern if all parasitic stages of $l$. frontalis were found on them. There are exceptional records from Carnivora: Mustelidae and humans. Main references: Filippova (1977), Gilot (1984), Tovornik (1991), Doby (1998), Guglielmone et al. (2014), Norte et al. (2015).

Ixodes howelli Cooley and Kohls, 1938: a Nearctic species with larvae, nymphs and adults usually found on Passeriformes: Hirundinidae, with records of larvae and nymphs on Passeriformes: Fringillidae and nymphs on Falconiformes: Falconidae (Kohls and Ryckman 1962; Webb et al. 1990; Durden and Keirans 1996; Guglielmone et al. 2014).

Ixodes jacksoni Hoogstraal, 1967: an Australasian species with all parasitic stages found on Suliformes: Phalacrocoracidae (Hoogstraal 1967; Dumbleton 1973; Dietrich et al. 2011; Guglielmone et al. 2014).
Ixodes kerguelenensis André and Colas-Belcour, 1942: a species established in Australasia and islands in the Atlantic, Indian and Pacific Oceans with all stages usually feeding on Procellariiformes: Procellariidae and Sphenisciformes: Spheniscidae, but adults and nymphs were also recovered from Procellariiformes: Diomedeidae, and adult ticks on Procellariiformes: Pelecanoididae. An undetermined stage of I. kerguelenensis has been found on Psittaciformes: Strigopidae. Main references: Wilson (1970b), Dietrich et al. (2011), Guglielmone et al. (2014).

Ixodes kohlsi Arthur, 1955: an Australasian species with all parasitic stages usually found on Sphenisciformes: Spheniscidae, with records of adult ticks on Suliformes: Phalacrocoracidae and Procellariiformes: Procellariidae. Undetermined stages of $I$. kohlsi have been found on Pelecaniformes: Sulidae and Charadriiformes: Sternidae. It was also found on humans. Main references: Roberts $(1960,1970)$, Dietrich et al. (2011), Guglielmone et al. (2014).

Ixodes laysanensis Wilson, 1964: a species established in Central Pacific islands where their adults and nymphs feed on Charadriiformes: Scolopacidae and Procellariiformes: Diomedeidae. Adult ticks were also found on Charadriiformes: Laridae, Suliformes: Fregatidae, Sulidae, and Phaethontiformes: Phaethontidae, while larvae were determined on Charadriiformes: Sternidae but also on a NMB (Passeriformes: Fringillidae). Main references: Wilson (1964a), Kohls and Clifford (1967), Dietrich et al. (2011), Guglielmone et al. (2014).

Ixodes lividus Koch, 1844: a Palearctic species whose larvae, nymphs and adults are usually found on Passeriformes: Hirundinidae; adults and larvae on Coraciiformes: Alcedinidae, nymphs and larvae on Coraciiformes: Meropidae, Passeriformes: Paridae, larvae on Passeriformes: Passeridae. Undetermined stages of I. lividus were recovered from Passeriformes: Alaudidae, Sturnidae and Turdidae. Main references: Fedorov (1972), Filippova (1977), Ulmanen et al. 1977, Gilot (1984), Trilar (2004), Guglielmone et al. (2014).

Ixodes mitchelli Kohls, Clifford and Hoogstraal, 1970: a Palearctic species whose larvae, nymphs and adults are found on Galliformes: Phasianidae (Clifford et al. 1975; Guglielmone et al. 2014).

Ixodes paranaensis Barros-Battesti, Arzua, Pichorim and Keirans, 2003: a Neotropical species whose larvae, nymphs and adults feed on Apodiformes: Apodidae (Barros-Battesti et al. 2003; Dantas-Torres et al. 2009; Tolesano-Pascoli et al. 2014; Luz et al. 2016).

Ixodes percavatus Neumann, 1906: a species established in islands in the Atlantic and Indian Oceans. All parasitic stages were found on Procellariiformes: Diomedeidae (ANL). Undetermined tick stages were found on Procellariiformes: Pelecanoididae and Hydrobatidae; Sphenisciformes: Spheniscidae. One 
larva was found on NMB (Passeriformes: Turdidae). Main references: Anastos (1954), Dietrich et al. (2011), Guglielmone et al. (2014).

Ixodes rothschildi Nuttall and Warburton, 1911: a Palearctic species whose larvae, nymphs and adults are found on Procellariiformes: Procellariidae and Charadriiformes: Alcidae, and adults and nymphs also recovered from Charadriiformes: Laridae. Undetermined specimens of $I$. rothschildi were also collected from Suliformes: Phalacrocoracidae. Main references: Arthur (1953, 1955, 1958), Zumpt (1952), Dietrich et al. (2011), Guglielmone et al. (2014).

Ixodes signatus Birula, 1895: a Nearctic-Palearctic species whose larvae, nymphs and adults usually feed on Suliformes: Phalacrocoracidae but also found on Charadriiformes: Alcidae and Laridae. Nymphs and adults of $I$. signatus have been recovered from the NMB (Passeriformes: Fringillidae) and adult ticks from Carnivora: Otariidae. Main references: Gregson (1954, 1956), Kozlovskaya et al. (1968), Yamaguti et al. (1971), Filippova (1977), Schwan and Kelly (1981), Dietrich et al. (2011), Guglielmone et al. (2014)

Ixodes subterraneus Filippova, 1961: a Palearctic species with larvae, nymphs and adult ticks found on Passeriformes: Passeridae. Undetermined tick stages were found on Passeriformes (six families), Coraciiformes: Coraciidae, Falconiformes: Falconidae, Galliformes: Phasianidae and Strigiformes: Strigidae. Main references: Filippova (1961, 1977), Guglielmone et al. (2014).

Ixodes turdus Nakatsudi, 1942: a Palearctic species with larvae, nymphs and adults ticks found on Galliformes: Phasianidae and Passeriformes (eight families); adults and larvae were also recovered from Strigiformes: Strigidae. There is also an odd larval record of $I$. turdus on Rodentia: Muridae and this tick has been also found biting humans. Main references: Asanuma and Kosaka (1955), Yamaguti et al. (1971), Miyamoto et al. (2000), Yamauchi (2001), Kim et al. (2009), Kang et al. (2013), Guglielmone et al. (2014).

Ixodes unicavatus Neumann, 1908: a Palearctic species with larvae, nymphs and adults usually found on Suliformes: Phalacrocoracidae; larvae were also recovered from Passeriformes: Motacillidae. Undetermined stages of $I$. unicavatus have been found on Charadriiformes: Alcidae and Falconiformes: Falconidae. Main references: Filippova (1977), Guiguen et al. (1987), Martyn (1988), Jaenson et al. (1994), Dietrich et al. (2011), Guglielmone et al. (2014).

Ixodes uriae: a species with a circumpolar distribution including localities in the Afrotropical, Australasian, Nearctic and Neotropical Regions. Larvae, nymph and adults of $I$. uriae feed on a great variety of Aves as
Charadriiformes: Alcidae and Lariidae, Procellariiformes: Diomedeidae, Sphenisciformes: Spheniscidae and Suliformes: Phalacrocoracidae. Nymphs and adult ticks were recovered from Charadriiformes: Stercoraridae, Procellariiformes: Procellariidae and Hydrobatidae. Unknown stages of $I$. uriae were also found on Anseriformes: Anatidae, Charadriiformes: Scopolacidae, Passeriformes (four families), Suliformes: Sulidae with some exceptional records on mammals of the orders Carnivora and Rodentia plus humans: Main references: Eley (1977), Jaenson and Jensen (2007), Baggs et al. (2011), Dietrich et al. (2011), Guglielmone et al. (2014), Muñoz-Leal and González-Acuña (2015).

\section{ANALYSIS BY HOST TAXA}

Only one species ( $I$. anatis) is strictly bound to Palaeognathae. The six species of Haemaphysalis and 14 of the 25 species of Ixodes feed on NMB (table 1). Four species of Haemaphysalis are found exclusively (H. megalaimae, $H$. minuta) and non-exclusively $(H$. doenitzi, $H$. wellingtoni) in the Oriental Region, while $H$. chordeilis is a Nearctic species and $H$. hoodi an Afrotropical taxon. The majority of the 14 species of Ixodes that feed on NMB are found in the Palearctic, seven exclusively there as follows: I. berlesei, I. caledonicus (with some records on MB), I. frontalis, I. lividus, I. mitchelli, I. subterraneus, I. turdus, while I. arboricola is established in the Oriental and Palearctic regions; three are Nearctic species, I. baergi and $I$. howelli (exclusively) plus $I$. brunneus which is a Nearctic-Neotropical tick, I. anatis is an Australasian species, I. collocaliae is an Australasian-Oriental taxon, and $I$. paranaensis is found exclusively in the Neotropical region. One species, the cosmopolitan (Australasian-Afrotropical-Nearctic-Neotropical) I. auritulus feeds on $\mathrm{MB}$ and $\mathrm{NMB}$ (table 1 ).

Amblyomma loculosum (Afrotropical-AustralasianOriental) and ten species of Ixodes parasitize exclusively MB. Five of these ten species are established in the Australasian Region, three only there (I. eudyptidis, I. jacksoni, I. kohlsi), I. kerguelenensis is found in Australasian and islands in the Atlantic, Indian and Pacific Oceans, while $I$. uriae is circumpolar with records at localities of the adjacents zoogeographical regions including Australasian. Two species, I. rothschildi and I. unicavatus, are Palearctic, I. signatus is a Nearctic-Palearctic taxon; I. percavatus is established in islands in the Atlantic and Indian Oceans and, finally, I. laysanensis is established in islands of the Pacific Ocean. There are a few record of immatures stages of I. laysanensis, I. signatus and I. unicavatus from NMB that do not defy the condition of these species as bound to MB. 
Table 1. Orders of marine (M) and non-marine (NM) Aves crucial for larvae, nymphs and adult ticks of species of Ixodidae.

\begin{tabular}{|c|c|c|c|}
\hline \multirow[t]{2}{*}{ Species of tick } & \multicolumn{3}{|c|}{ Hosts } \\
\hline & Adults & Nymphs & Larvae \\
\hline Amblyomma loculosum & $\begin{array}{l}\text { Charadriiformes (M) } \\
\text { Suliformes (M) }\end{array}$ & $\begin{array}{l}\text { Charadriiformes (M) } \\
\text { Procellariiformes (M) Suliformes (M) }\end{array}$ & $\begin{array}{l}\text { Charadriiformes (M) } \\
\text { Suliformes (M) }\end{array}$ \\
\hline Haemaphysalis chordeilis & $\begin{array}{c}\text { Anseriformes (NM) Caprimulgiformes (NM) } \\
\text { Galliformes (NM) } \\
\text { Passeriformes (NM) }\end{array}$ & $\begin{array}{l}\text { Accipitriformes (NM) } \\
\text { Galliformes (NM) } \\
\text { Passeriformes (NM) }\end{array}$ & $\begin{array}{l}\text { Galliformes (NM) } \\
\text { Passeriformes (NM) }\end{array}$ \\
\hline H. doenitzi & $\begin{array}{c}\text { Accipitriformes (NM) Coraciiformes (NM) } \\
\text { Cuculiformes (NM) } \\
\text { Falconiformes (NM) } \\
\text { Galliformes (NM) } \\
\text { Gruiformes (NM) Passeriformes (NM) Strigiformes } \\
\text { (NM) }\end{array}$ & $\begin{array}{l}\text { Accipitriformes (NM) Cuculiformes (NM) } \\
\text { Falconiformes (NM) } \\
\text { Galliformes (NM) } \\
\text { Passeriformes (NM) Piciformes (NM) } \\
\text { Strigiformes (NM) }\end{array}$ & $\begin{array}{l}\text { Cuculiformes (NM) } \\
\text { Galliformes (NM) } \\
\text { Passeriformes (NM) }\end{array}$ \\
\hline H. hoodi & $\begin{array}{c}\text { Accipitriformes (NM) Ciconiiformes (NM) } \\
\text { Coraciiformes (NM) Cuculiformes (NM) } \\
\text { Falconiformes (NM) Galliformes (NM) Gruiformes } \\
\text { (NM) } \\
\text { Passeriformes (NM) }\end{array}$ & $\begin{array}{l}\text { Columbiformes (NM) } \\
\text { Cuculiformes (NM) Galliformes (NM) } \\
\text { Passeriformes (NM) }\end{array}$ & $\begin{array}{l}\text { Columbiformes (NM) } \\
\text { Cuculiformes (NM) Galliformes (NM) } \\
\text { Passeriformes (NM) }\end{array}$ \\
\hline H. megalaimae & Piciformes (NM) & Piciformes (NM) & Piciformes (NM) \\
\hline H. minuta & Galliformes (NM) & $\begin{array}{c}\text { Cuculiformes (NM) } \\
\text { Galliformes (NM) Passeriformes (NM) }\end{array}$ & Galliformes (NM) Passeriformes (NM) \\
\hline H. wellingtoni & $\begin{array}{c}\text { Accipitriformes (NM) Coraciformes (NM) } \\
\text { Cuculiformes (NM) } \\
\text { Galliformes (NM) } \\
\text { Passeriformes (NM) }\end{array}$ & $\begin{array}{c}\text { Accipitriformes (NM) } \\
\text { Cuculiformes (NM) Galliformes (NM) } \\
\text { Passeriformes (NM) }\end{array}$ & $\begin{array}{l}\text { Charadriiformes (NM) } \\
\text { Cuculiformes (NM) Galliformes (NM) } \\
\text { Gruiformes (NM) Passeriformes (NM) }\end{array}$ \\
\hline Ixodes anatis & $\begin{array}{c}\text { Anseriformes (NM) } \\
\text { Struthioniformes (NM) }\end{array}$ & $\begin{array}{c}\text { Anseriformes (NM) } \\
\text { Struthioniformes (NM) }\end{array}$ & Struthioniformes (NM) \\
\hline I. arboricola & $\begin{array}{c}\text { Charadriiformes (NM) } \\
\text { Falconiformes (NM) } \\
\text { Passeriformes (NM) Piciformes (NM) } \\
\text { Strigiformes (NM) }\end{array}$ & $\begin{array}{l}\text { Passeriformes (NM) } \\
\text { Piciformes (NM) Strigiformes (NM) }\end{array}$ & $\begin{array}{c}\text { Accipitriformes (NM) Columbidae (NM) } \\
\text { Passeriformes (NM) } \\
\text { Piciformes (NM) } \\
\text { Strigiformes (NM) }\end{array}$ \\
\hline I. auritulus & $\begin{array}{c}\text { Accipitriformes (NM) Charadriiformes (M) } \\
\text { Columbiformes (NM) } \\
\text { Falconiformes (NM) } \\
\text { Galliformes (NM) } \\
\text { Passeriformes (NM) } \\
\text { Piciformes (NM) Procellariiformes (M) } \\
\text { Sphenisciformes (M) } \\
\text { Tinamiformes (NM) }\end{array}$ & $\begin{array}{l}\text { Apodiformes (NM) Columbiformes (NM) } \\
\text { Falconiformes (NM) Galliformes (NM) } \\
\text { Passeriformes (NM) Procellariiformes (M) } \\
\text { Tinamiformes (NM) }\end{array}$ & $\begin{array}{l}\text { Apodiformes (NM) Falconiformes (NM) } \\
\text { Galliformes (NM) Passeriformes (NM) }\end{array}$ \\
\hline I. baergi & Passeriformes (NM) & Passeriformes (NM) & Passeriformes (NM) \\
\hline I. berlesei & Apodiformes (NM) Passeriformes (NM) & Apodiformes (NM) Passeriformes (NM) & Apodiformes (NM) Passeriformes (NM) \\
\hline I. brunneus & $\begin{array}{c}\text { Galliformes (NM) Passeriformes (NM) Piciformes } \\
\text { (NM) } \\
\text { Strigidae (NM }\end{array}$ & $\begin{array}{c}\text { Galliformes (NM) } \\
\text { Passeriformes (NM) }\end{array}$ & Galliformes (NM) Passeriformes (NM) \\
\hline I. caledonicus & $\begin{array}{c}\text { Apodiformes (NM) } \\
\text { Columbiformes (NM) } \\
\text { Falconiformes (NM) } \\
\text { Passeriformes (NM) } \\
\text { Procellariformes (M) } \\
\end{array}$ & $\begin{array}{l}\text { Apodiformes (NM) } \\
\text { Columbiformes (NM) } \\
\text { Falconiformes (NM) } \\
\text { Passeriformes (NM) }\end{array}$ & $\begin{array}{l}\text { Apodiformes (NM) } \\
\text { Columbiformes (NM) } \\
\text { Falconiformes (NM) } \\
\text { Passeriformes (NM) }\end{array}$ \\
\hline I. collocaliae & Apodiformes (NM) & Apodiformes (NM) & Apodiformes (NM) \\
\hline I. eudyptidis & Charadriiformes (M) Sphenisciformes (M) & $\begin{array}{c}\text { Charadriiformes (M) Sphenisciformes (M) } \\
\text { Suliformes (M) }\end{array}$ & $\begin{array}{c}\text { Charadriiformes (M) Sphenisciformes (M) } \\
\text { Suliformes (M) }\end{array}$ \\
\hline I. frontalis & Passeriformes (NM) & $\begin{array}{c}\text { Passeriformes (NM) } \\
\text { Piciformes (NM) }\end{array}$ & Passeriformes (NM) \\
\hline I. howelli & Passeriformes (NM) & $\begin{array}{l}\text { Passeriformes (NM) } \\
\text { Falconiformes (NM) }\end{array}$ & Passeriformes (NM) \\
\hline I. jacksoni & Suliformes (M) & Suliformes (M) & Suliformes (M) \\
\hline I. kerguelenensis & $\begin{array}{l}\text { Procellariformes (M) } \\
\text { Sphenisciformes (M) }\end{array}$ & Procellariformes (M) Sphenisciformes (M) & Procellariformes (M) Sphenisciformes (M) \\
\hline I. kohlsi & $\begin{array}{l}\text { Procellariiformes (M) } \\
\text { Sphenisciformes (M) } \\
\text { Suliformes (M) }\end{array}$ & Sphenisciformes (M) & Sphenisciformes (M) \\
\hline I. laysanensis & $\begin{array}{c}\text { Charadriiformes (M) } \\
\text { Phaethontiformes (M) Procellariiformes (M) } \\
\text { Suliformes (M) }\end{array}$ & Charadriiformes (M) Procellariiformes (M) & $\begin{array}{l}\text { Charadriiformes (M) } \\
\text { Passeriformes (NM) }\end{array}$ \\
\hline I. lividus & $\begin{array}{l}\text { Coraciiformes (NM) } \\
\text { Passeriformes (NM) }\end{array}$ & $\begin{array}{l}\text { Coraciiformes (NM) } \\
\text { Passeriformes (NM) }\end{array}$ & $\begin{array}{l}\text { Coraciiformes (NM) } \\
\text { Passeriformes (NM) }\end{array}$ \\
\hline I. mitchelli & Galliformes (NM) & Galliformes (NM) & Galliformes (NM) \\
\hline I. paranaensis & Apodiformes (NM) & Apodiformes (NM) & Apodiformes (NM) \\
\hline I. percavatus & Procellariiformes (M) & Procellariiformes (M) & Procellariiformes (M) Passeriformes (NM) \\
\hline I. rothschildi & Charadriiformes (M) Procellariiformes (M) & Charadriiformes (M) Procellariiformes (M) & Charadriiformes (M) Procellariiformes (M) \\
\hline I. signatus & Charadriiformes (M) Suliformes (M) & $\begin{array}{c}\text { Charadriiformes (M) } \\
\text { Passeriformes (NM) Suliformes (M) }\end{array}$ & $\begin{array}{l}\text { Charadriiformes (M) Passeriformes (NM) } \\
\text { Suliformes (M) }\end{array}$ \\
\hline I. subterraneus & Passeriformes (NM) & Passeriformes (NM) & Passeriformes (NM) \\
\hline I. turdus & $\begin{array}{l}\text { Galliformes (NM) } \\
\text { Passeriformes (NM) } \\
\text { Strigiformes (NM) }\end{array}$ & Galliformes (NM) Passeriformes (NM) & $\begin{array}{c}\text { Galliformes (NM) Passeriformes (NM) } \\
\text { Strigiformes (NM) }\end{array}$ \\
\hline I. unicavatus & Suliformes (M) & Suliformes (M) & $\begin{array}{c}\text { Suliformes (M) } \\
\text { Passeriformes (NM) }\end{array}$ \\
\hline I. uriae & $\begin{array}{c}\text { Charadriiformes (M) } \\
\text { Procellariiformes (M) } \\
\text { Sphenisciformes (M) Suliformes (M) }\end{array}$ & $\begin{array}{c}\text { Charadriiformes (M) } \\
\text { Procellariiformes (M) } \\
\text { Sphenisciformes (M) Suliformes (M) }\end{array}$ & $\begin{array}{l}\text { Charadriiformes (M) Procellariiformes (M) } \\
\text { Sphenisciformes (M) Suliformes (M) }\end{array}$ \\
\hline
\end{tabular}




\section{ANALYSIS BY REGION}

The Australasian I. jacksoni is close to I. uriae according to Hoogstraal (1967) and some workers treated these species as the only members of the genus Ceratixodes, while others included them in the subgenus Ceratixodes. All Australasian species above except I. kerguelenensis are included in the Australasian Ixodes + uriae by Barker and Murrell (2004) who added I. laysanensis (central Pacific Islands) to this group; however this assemblage is controversial as all these species but $l$. jacksoni belong to the worldwide distributed subgenus Multidentatus and where included in the Australasia Ixodes + uriae just because their relationship with the Australasian Zoogeographic Region without morphological considerations. Nevertheless, the Australasian contribution of Ixodes that feed on $M B$ is noteworthy considering that there are only 28 species found exclusively and non-exclusively in this zoogeographic region versus 63 species in the Palearctic Region (61 species in Guglielmone et al., 2014 plus I. ariadnae and I. inopinatus). The genus Ixodes is best represented in the Afrotropical Region; there are 69 species of Ixodes in this region (68 in Guglielmone et al. 2014 plus I. microgalei), 64 are found only there, but birds are irrelevant to support all parasitic stages of African Ixodes.

\section{Discussion}

\section{IXODIDAE AND AVES}

Many species of Prostriata and Metastriata feed on birds, but avian-feeding is probably not relevant for survival because avian records are exceptional. For some other taxa the situation is uncertain due insufficient field data (Guglielmone et al., 2014). Conversely, Aves are vital for the existence of some species because the immature stages feed mainly on Aves and adult ticks feed largely on Mammalia, a hostparasite relationships that will not be treated here. The analysis involved only those species whose larvae, nymphs and adult ticks feed on Aves. Surely there are more than 32 species treated here that depend on Aves for survival of all parasitic stages, but hosts are unknown for one or two parasitic stages in several taxa mostly known as parasites of birds. This is especially evident for Ixodes with 17 species under this condition but not relevant for Metastriata (Guglielmone et al. 2014). The proportion of Ixodes with all parasitic stages feeding on Aves (19\%) is substantially higher than for Haemaphysalis, with $7 \%$ of all species with stages feeding on birds. All the species that feed exclusively on MB are Ixodes with the exception of $A$. loculosum. Conversely the modern Ixodidae (Rhipicephalinae), which contains the genera Anomalohimalaya, Cosmiomma, Dermacentor, Hyalomma,
Nosomma, Rhipicentor and Rhipicephalus, have no species with all parasitic stages bound to Aves, a condition which may have evolutionary importance and already noted by Zumpt (1952) in relation to seabirds ticks. Evidently Aves are more important as hosts for Prostriata than for Metastriata, probably indicating an old host-parasitic relationship with evolutionary implications as already emphasized by other workers mentioned in the Introduction.

The six species of Haemaphysalis feeding on a variety of NMB are predominantly from the Oriental Region but jointly encompasses all zoogeographic regions except the Neotropical region. These species are classified in three subgenera, four in Ornithophysalis (H. doenitizi, H. hoodi, H. megalaimae, H. minuta), one ( $H$. wellingtoni) in Kaiseriana, and one $(H$. chordeilis) in Aboimisalis; the first two subgenera are "structurally advanced" and the third "structurally primitive" according to Hoogstraal and Kim (1985) but this subgeneric division of Haemaphysalis has shown inconsistencies (Burger et al. 2013). The relevance of these species of Haemaphysalis for the origin and evolution of this genus remains unclear.

At first sight the scenario for the 14 species of Ixodes from NMB is similar to the scenario depicted for Haemaphysalis above. These Ixodes shows a Palearctic predominance but jointly encompasses all zoogeographic regions. According to the subgeneric division of Clifford et al. (1973) these 14 species represent five subgenera (Ixodes, Multidentatus, Pholeoixodes, Scaphixodes and Sternalixodes) and one species (I. collocaliae) is left wihout subgeneric status although others classified it as Xiphixodes. The subgeneric division in Ixodes is not resolved as shown by Klompen (1999) and Guglielmone et al. (2006), as is not resolved either for several genera forming Metastriata. Nevertheless, a clade formed by the Palearctic I. berlesei, I. caledonicus, I. mitchelli and the Nearctic I. howelli (all from NMB) plus the parasites of $\mathrm{MB}$ I. unicavatus (Palearctic) and I. signatus (NearcticPalearctic) form a rather homogeneous group in Clifford et al. (1973) under the subgenus Scaphixodes and Filippova (1977) agreed, which is not irrelevant because there is disagreement in the subgeneric division of Ixodes between these authors. Filippova (1977) also includes I. rothschildi (Palearctic) into Scaphixodes. It should be of value to explore if this Palearctic-Nearctic group of Ixodes is basal for Ixodes sensu stricto (or Prostriata not included in the Australasian (xodes + uriae).

The Ceratixodes I. uriae and I. jacksoni plus eight species of Ixodes feed on $\mathrm{MB}$ and all receive the treatment of "primitive" Ixodes by Zumpt (1951, 1952), Morel (1969), Filippova (1977), Balashov (1994) and Kolonin (2008). They are currently parasites of Neognathae that were established before the K-Pg boundary (Pacheco et al., 2011) and these tick species (or their ancestors) probably surpassed this boundary along with these types of hosts. The eight species with the exclusion of $I$. uriae and I. jacksoni are found in the 
Australasian, Nearctic and Palearctic Zoogeographic Regions, and islands of the Atlantic, Indian and Pacific Oceans; five of them (I. eudyptidis, I. kerguelenensis, I. kohlsi, I. laysanensis and I. percavatus) are included in the subgenus Multidentatus, two (I. signatus and $I$. unicavatus) are Scaphixodes and $I$. rothschildi is classified as Multidentatus by Clifford et al. (1973) and as Scaphixodes by Filippova (1977). All or some of these species may belong to a same hypothetical lineage that radiated from Australasia to colonize oceanic islands and the northern hemisphere in a similar way as it is proposed for I. uriae by Dietrich et al. (2014), or eventually, may be part of the hypothetical Palearctic-Nearctic basal tick clade discussed above.

\section{HYPOTHESIS ABOUT EVOLUTION OF THE AUSTRALASIAN IXODES + URIAE AND PROSTRIATA}

By definition the lineage of Australasian Ixodes + uriae should have originated in Australasia, but Mans et al. (2012) did not discard its occurrence in South American. Dietrich et al. (2014) stated that $I$. uriae and I. holocyclus split $97 \pm 21$ mya (Cretaceous). Hypothetically, it should be inferred that the ancestor of $I$. uriae was a parasite of feathered dinosaurs of the clade Avialae (Theropoda) that continued its evolutionary path to reach Neornithes, while alleged $I$. holocyclus-like species shifted to ancient mammal hosts. Actually I. holocyclus is a catholic feeder with a strong presence as a parasite of Australasian marsupials (Guglielmone et al., 2014). The earliest date for the onset of $I$. holocyclus-marsupials relationship is about 70 mya (Mitchell et al., 2014; Gallus et al., 2015) and probably consolidated after the K-Pg boundary. Dietrich et al. (2014) dated the split of I. uriae and I. holocyclus when Australia and Antarctic was still connected and available mammal hosts there were monotremes (Archer et al., 1985; Musser, 2003). Avialae was established by early Cretaceous in Australasia (Chiappe, 1996; Close et al., 2009; Fitzgerald et al., 2012; Martin et al., 2014) and by late Cretaceous in Antarctica (Chiappe, 1996; Clarke et al., 2005) therefore this split event should have occurred in Australasia coinciding with the origin of $I$. uriae proposed by Dietrich et al. (2014). Probably Australasian Ixodes uriae passed the K-Pg boundary feeding on $\mathrm{MB}$ and Ixodes holocyclus or their ancestors, surpassed it as a parasite of Monotremata (eventually on early Australian marsupials or both).

The date of the split of $I$. uriae and I. holocyclus-like ticks should not be confused with the origin of the Australasian Ixodes + uriae clade. The oldest fossil record of Australasian Avialae is from early Cretaceous (125-113 mya) (Close et al., 2009) a date matching the age of the first fossil record of Monotremata (Musser, 2003). The latter author emphasized that early Cretaceous was a time of diversification of monotremes rather than a time of origin that according to van Rheede et al. (2006) occurred in late Triassic (231-
217 mya). Likely Australasian Ixodes + uriae clade evolved before the date of fossil records of Avialae and Monotremata listed above with some ticks probably radiating earlier than the time of split of $I$. uriae and I. holocyclus. It is uncertain if the origin of the clade has to be traced back to early Triassic in concordance with the origin of Monotremata although this time is in accord with the proposal of Mans et al. (2012). There are few records of $I$. holocyclus from monotremes (Roberts, 1970, Gofton et al., 2015) but $I$. ornithorhynchi (all tick stages known) has been found only on Ornithorhynchidae (platypus), while I. zaglossi feeds on Tachyglossidae (echidna) but only the female tick is known, I. luxuriosus and I. tasmani have been recorded as parasite of Monotremata: Tachyglossidae, among other hosts (Roberts, 1970, Guglielmone et al. 2014). Ixodes ornithorhynchi, the most "primitive" of Australasian Ixodes according to Morel (1969), and I. tasmani are members of the Australasian Ixodes + uriae group in Klompen et al. (2000) while I. luxuriosus and $I$. zaglossi are included in this clade by Barker and Murrell (2004). Perhaps, some of the actual Australasian Ixodes parasites of marsupials and eutherians are derived from ancestors that fed on ancient mammals with no choice than to feed on monotremes if their life history started in Australasia before than 70 mya, with species as I. ornithorhynchi still bound to Monotremata.

Neornithes basal divergences occurred before the K-Pg boundary with several orders and crown groups of Aves well represented before the catastrophic event (Pacheco et al., 2011). Some of these avian orders are actually important for the sustenance of $I$. uriae as presented in Muñoz-Leal and González-Acuña (2015). After surpassing the K-Pg boundary I. uriae remained an Australasian species that started to radiated in early Miocene (22 mya) to reach South Atlantic and Indian Ocean territories first and the northern hemisphere thereafter (Dietrich et al., 2014), in coincidence with strong avian radiation of Neornithes during this period (Benton, 2005).

Prostriata (Ixodes) originated in the Jurassic (196 \pm 27 mya) according to Jeyaprakash and Hoy (2009) and supported by Dietrich et al. (2014), but it is a Triassic event that took place $217 \pm 24$ mya in Mans et al. (2012). Both dates of Prostriata origin correspond to epochs before Pangaea started to break apart encompassing a period of more than 130 million years until K-Pg boundary. Hypothetically during this period several lines of Ixodidae should have radiated to cover niches of terrestrial vertebrates and some become extinct along with their hosts, a force that shaped the current tick situation in the opinion of many workers from Hoogstraal (1978) to Barker et al. (2014) and Mans et al. (2014) among others. Under this speculative scenario, likely first successful Prostriata (proto Ceratixodes?) fed on theropod dinosaurs and their descendants through marine Neornithes, being uncertain where this hypothetical event ocurred. 
Nevertheless, if late Triassic ancestral monotremes were involved in the evolution of Prostriata an Australasian origin for this event seems plausible.

In brief, it is proposed that actual $I$. uriae is the final expression of a natural history that started in an undetermined place in late Triassic - early Jurassic feeding on Theropoda giving rise to the Australasian Ixodes + uriae in an uncertain time period from late Triassic to early Cretaceous. This was followed by the split of the ancestor of $I$. uriae in late Cretaceous which surpassed the K-Pg boundary on marine Neornithes to finally radiate to colonize coastal environment in northern and southern hemispheres alongside the radiation of its neognathan hosts.

\section{HYPOTHESIS ABOUT THE ORIGIN OF IXODIDA AND IXODIDAE:}

Guglielmone et al. (2014) stated that $67 \%$ of hard tick species are only found on lands of this former super continent and only $18 \%$ in Laurasian territory; this biased distribution is considered here a result of the origin of Ixodida in Gondwanan lands. When it occurred is debatable and there are a vast arrange of hypothesis covering several periods of Paleozoic to Mesozoic epochs before, during and after Pangaea covering times when amphibians, dinosaurs and mammals originated and several massive extinctions of vertebrates occurred. Great part of the disagreement among theories is due to lack of tick fossils earlier than Cretaceous period.

Black and Piesman (1994) analyzed 165 mitochondrial gene sequences and placed the origin of Ixodidae not earlier than 140 mya bound to appearance of first Aves in coincidence with the time proposal of Filippova (1977) who based her decision on morphological primitiveness of Ixodes subgenera such as Ceratixodes, Exopalpiger, Scaphixodes and Sternalixodes. Klompen et al. (2000) adhered to a Cretaceous origin of Ixodidae and placed it in Australia after the almost complete isolation of the country in mid-late time of this period. Balashov (1994) studied the current distribution of genera of Ixodidae and located the arisen of the family in late Triassic-early Jurassic well before Pangaea starts to break apart with most primitive mammals as ancestral hosts. Hoogstraal (1978), Hoogstraal and Aeschlimann (1982) and Hoogstraal and Kim (1985) hypothesized about Ixodida origin in late Permian-early Triassic as a parasite of reptiles that shortly diverged into Argasidae which mostly maintained the primitive morphological features and Ixodidae that shown a diverse morphological pattern from primitive to advanced species. Mans et al. (2011) analyzed phylogenetically $18 \mathrm{~S}$ nuclear and $16 \mathrm{~S}$ mitochondrial genes of $N$. namaqua to conclude that Ixodida originated in mid-late Permian (270-260 mya in Gondwanan lands, specifically in the Karoo Basin (currently Africa), as parasites of therapsids but later changed hosts to feed on diapsids. Schulze (1937) claimed that Ixodida aroused during the Permian as a collateral branch of Anthracomarti (= Trigonotarbida) feeding on reptiles, while Morel (1969) also stated that Ixodida appeared during the Permian as parasites of reptiles. Jeyaprakash and Hoy (2009) used sequences of several mitochondrial genes to resolve the phylogeny of Chelicerata and located the origin of Ixodida at late Carboniferous-early Permian (327-273 mya) feeding on amphibians, followed by Ixodidae originated during late Permian-Triassic (269-213) as parasites of reptiles. Mans et al. $(2012,2016)$ presented a phylogenetic and time divergence analysis of Ixodida based on 16S, $18 \mathrm{~S}$ and mitochondrial protein genes and a molecular clock with Xiphosura-Pycnogidae node dated 445 mya to calibrated the root of the tree and minimum age for Metastriata set up at 100 mya; These authors placed the origin of Ixodida in the Carboniferous Period in northern Gondwana (currently eastern Africa) and migration to the Karoo Basin in southern Africa during late Permian considering $N$. namaqua as the closest extant relative to the common ancestral tick lineage and placed the origin of Ixodidae in the Triassic. Oliver (1989) supported an origin of Ixodida in the Devonian feeding on amphibians based on a statement of Lindquist (1984) that Acarina ancestral stock have arisen in Late Silurian Period and a great radiation of Acarina in the Devonian; this view was supported by Dobson and Barker (1999) which located this event in territories of the actual Australia country, and by Barker et al. (2014) who disputed the basal nature of $N$. namaqua as well as the African Gondwanan origin of Ixodida, forwarding different hypothetical alternatives to the proposal in Mans et al. (2012).

From the many hypotheses above the proposals of Mans et al. $(2012,2016)$ and Barker et al. (2014) are more elaborated phylogenetically than the others, and present discussions quite specific about different sites for the origin of Ixodida in Gondwanan territories. These authors coincide in supporting holothyrid mites as the ancestors of Ixodida, conversely rejecting the competing theory that ticks evolved from mesotigmatid mites as proposed by Karg and Schorlemmer $(2008,2013)$ and some uncertainties of holothyrids basal position to Ixodida in Burger et al. (2014). Dunlop and Penney (2012) prefer the hypothesis of holothyrids basal to Ixodida but did not reject the second option showing that this matter is not resolved.

The ancient origin of $N$. namaqua in Mans et al. (2012) is accepted by Barker et al. (2014); this might favor a presumptive origin of Ixodida in the Carboniferous or perhaps earlier although additional evidence are needed to confirm it. Barker et al. (2014) based their hypothesis of a Devonian Australian origin of Ixodida on the presence there of six of eight main tick lineages (Amblyomminae, Argasinae, Bothriocrotinae, Haemaphysalinae, Ixodinae and Ornithodorinae) and the Australian endecimity of holthyrid mites, but the 
Afrotropical Zoogeographic Region contains seven of the eight subfamilies of ticks used in Barker et al. (2014) (Amblyomminae, Argasinae, Haemaphysalinae, Ixodinae, Nuttalliellinae, Ornithodorinae and Rhipicephalinae), and Holothyrida is not restricted to Australia (Walter and Proctor, 2013). Africa split from Gondwana about 130 mya carrying fauna originated in African Gondwana and derived fauna bringing some doubts about African origin of Nuttalliellidae postulated by Mans et al. $(2011,2012,2016)$ as these authors supported their position by the actual limited distribution of $N$. namaqua in Africa, but its actual range may also be a relic of a former ampler distribution as stated in Barker et al. (2014). Notably, Mans et al. (2015) treated N. namaqua as a tick with a wide geographic distribution, but we are unaware of new reports apart from those records long known from South Africa and Tanzania. Barker et al. (2014) supported that labyrinthodont amphibians were the original hosts of Ixodida and this event occurred in the part of Gondwana that became the actual Australia country. The term laberynthodont is taxonomical undefined for a group of paleo vertebrates nonrestricted to the region occupated by Australia in Gondwana. Australia was connected with South America, Africa, Antarctic and India before the formation of Pangaea and maintained these connections when the continent split into Gondwana and Laurasia to become an island when finally Australia separated from Antarctic about 40 mya. Therefore, Ixodida may have arisen in Australia in Devonian or Carboniferous Periods and spread to other lands, or the opposite including a hypothetical introduction of Antarctic paleofauna. Most probably the Motherland of Ixodida is Gondwana but, as in the case of Prostriata, under current evidence is unknown where this event precisely occurred.

Prostriata emergence was followed by radiation of Metastriata in the Cretaceous according to Mans et al. (2012). Metastriata group has been considered of Australasian origin (Klompen et al. 1997) with almost no dispute but Mans et al. (2012) presented a South American alternative. Burger et al. (2012, 2013) soundly proposed that "Amblyomma elaphense" (formerly a "primitive" Aponomma) does not belong to Amblyomma but to a new still undefined genus. Burger et al. (2013) stated that probably " $A$. elaphense" is basal to Metastriata, conversely displaced Bothriocroton (Australasian) from this position, an outcome already anticipated by Keirans and Klompen (1996). "Amblyomma elaphense" is a Nearctic species parasite of Squamata: Colubridae in the Chihuahuan desert ecoregion (Guglielmone et al. 2014); perhaps the actual range of this species is a vestige of a clade originated in lands including in the actual Nearctic Region or a relict of an ample past range, bringing additional uncertainties where major evolutionary tick events (arisen of Ixodida, Ixodidae, Prostriata, Metastriata) occurred.

\section{Acknowledgements}

Support for the authors was provided by the Instituto Nacional de Tecnología Agropecuaria, the Asociación Cooperadora of EEA-INTA Rafaela and Consejo Nacional de Investigaciones Científicas y Técnicas, Argentina.

\section{References}

Aeschlimann A. 1967. Biologie et écologie des tiques (Ixodoidea) de Cote d'Ivoire. Acta Trop. 24: 281-405.

Anastos G. 1954. Description of a tick, Ixodes percavatus Neumann, 1906, from Tristan da Cunha. Res. Norwegian Exped. Tristan da Cunha 1937-1938, 27: 1-4.

Anastos G, Smith CN. 1957. The male, nymph, and larva of Ixodes brunneus Koch (Acarina: Ixodidae). J. Parasitol. 43: 535-541.

Apanaskevich DA. 2013. First description of the nymph and larva of Dermacentor raskemensis (Acari: Ixodidae), parasites of pikas and other small mammals in Central Asia. J. Med. Entomol. 50: 959-964.

Apanaskevich MA, Apanaskevich DA. 2015. Reinstatement of Dernacentor bellulus (Acari: Ixodidae) as a valid species previously confused with $D$. taiwanensis and comparison of all developmental stages. J. Med. Entomol. 52: 573-595.

Apanaskevich DA, Apanaskevich MA. 2016. Description of two new species of Dermacentor Koch, 1844 (Acari: Ixodidae) from Oriental Asia. Syst. Parasitol. 93: 159-171.

Apanaskevich DA, Bermúdez SE. 2013. Description of a new Dermacentor Acari: Ixodidae) species, a parasite of wild mammals in Central America. J. Med. Entomol. 50: 11901201.

Apanaskevich DA, Bermudez SE. 2017. Description of a new species of Ixodes Latreille, 1795 (Acari: Ixodidae) and redescription of $I$. lasallei Méndez \& Ortiz, 1958, parasites of agoutis and pacas (Rodentia: Dasyproctidae, Cuniculidae) in Central and South America. Syst. Parasitol. 94: 463-475.

Apanaskevich DA, Duan W, Apanaskevich, MA, Filippova NA, Chen J. 2014. Redescription of Dermacentor everestianus Hirst (Acari: Ixodidae), a parasite of mammals in mountains of China and Nepal with synonymization of $D$. abaensis Teng and D. birulai Olenev. J. Parasitol. 100: 268-278.

Apanaskevich DA, Bandaranayaka KO, Apanaskevich MA, Rajakaruna RS. 2016. Redescription of Amblyomma integrum adults and immature stages. Med. Vet. Entomol. 30: 330-341.

Archer M, Flannery TF, Ritchie A, Molnar RE. 1985. First Mesozoic mammal from Australia - an early Cretaceous monotreme. Nature 318: 363-366.

Arthur DR. 1953. The systematic status of Ixodes percavatus var. rothschildi Nuttall \& Warburton. Parasitology 43: 222226.

Arthur DR. 1955. The larva of Ixodes rothschildi Nuttall \& Warburton, 1911. Ann. Mag. Nat. Hist. 8: 711-712. 
Arthur DR. 1958. A review of some ticks (Acarina: Ixodidae) of sea birds, including a consideration of other cognate material. I. Parasitology 48: 124-130.

Arthur DR 1960. A review of some ticks (Acarina: Ixodidae) of sea birds. Part II. The taxonomic problems associated with the Ixodes auritulus - percavatus group of species. Parasitology 50: 199-226.

Asanuma K, Kosaka K. 1955. Notes on a tick, Ixodes turdus Nakatsuji, 1942, found on birds in Japan. Bull. Biogeogr. Soc. Japan. (16-19) (Recent conceptions of Japanese fauna), pp. 192-196. In Japanese, NAMRU-3 translation 50.

Ash A, Elliot A, Godfrey A, Burmej H, Yazid Abdad M, Northover A, Wayne A, Morris K, Clode P, Lymbery A, Thompson RCA. 2017. Morphological and molecular description of Ixodes woyliei n. sp. (Ixodidae) with consideration for co-extinction with its critically endangered marsupial host. Parasites \& Vectors 10: 70.

Baggs EM, Stack SH, Finney-Crawling JR, Simon NP. 2011. Peromyscus maniculatus, a possible reservoir host of Borrelia garinii from the Gannet Islands off Newfoundland and Labrador. J. Parasitol. 97: 792-794.

Balashov YS. 1994. Importance of continental drift in the distribution and evolution of ixodid ticks. Entomol. Rev. 73: 42-50.

Barker SC, Murrell A. 2004. Systematics and evolution of ticks with a list of valid genus and species names. Parasitology 129 : S15-S36.

Barker SC, Walker AR, Campelo D. 2014. A list of 70 species of Australian ticks; diagnostic guides to and species account of Ixodes holocyclus (paralysis tick), Ixodes cornuatus (southern paralysis tick) and Rhipicephalus australis (Australian cattle tick); and consideration of the place of Australian in the evolution of ticks with comments on four controversial ideas. Int. J. Parasitol. 44: 941-953.

Barros-Battesti DM, Arzua M, Pichorim M, Keirans JE. 2003. Ixodes (Multidentatus) paranaensis $\mathrm{n}$. sp. (Acari: Ixodidae) a parasite of Streptoprocne biscutata (Sclater, 1865) (Apodiformes: Apodidae) birds in Brazil. Mem. Inst. Oswaldo Cruz 98: 93-102.

Bequaert JC. 1945. The ticks, or Ixodoidea, of the northeastern United States and eastern Canada. Entomol. Am. 25: 121-184

Benton MJ. 2005. Vertebrate paleontology, $3^{\text {rd }}$ edition. Blackwell Publishing, Oxford, 455 pp.

Bermúdez SE, Torres S, Aguirre Y, Domínguez L, Vega JAB. 2015. A Review of Ixodes (Acari: Ixodidae) parasitizing wild birds in Panama, with the first records of Ixodes auritulus and Ixodes bequaerti. Syst. Appl. Acarol. 20: 847-853.

Bhat HR, Sreenivasan MA. 1981. Further records of the ticks of some reptilian and mammalian hosts in the Kyasanur Forest disease area, Karnataka, India. Ind. J. Parasitol. 5: 207210.

Bishopp FC, Trembley HL. 1945. Distribution and hosts of certain North American ticks.J. Parasitol. 31: 1-53.

Black WC, Piesman J. 1994. Phylogeny of hard- and soft-tick taxa (Acari: Ixodidae) based on mitochondrial 16S rDNA sequences. Proc. Natl. Acad. Sci. 91: 10034-10038.

Black WC, Roehrdanz RL. 1998. Mitochondrial gene order is not conserved in arthropods: prostriate and metastriate ticks mitochondrial genomes. Mol. Biol. Evol. 15: 1772-1785.
Boshell J, Rajagopalan PK. 1968. Observations on the experimental exposure of monkeys, rodents and shrews to infestation of ticks in forest in Kyasanur Forest disease area. Ind. J. Med. Res. 56: 573-588.

Brusatte SL, O'Connor JK, Jarvis ED. 2015. The origin and diversification of birds. Curr Biol. 25: 888-898.

Burger TD, Shao R, Beati L, Miller H, Barker SC. 2012. Phylogenetic analysis of ticks (Acari: Ixodida) using mitochondrial genomes and nuclear rRNA genes indicates that the genus Amblyomma is polyphyletic. Mol. Phyl. Evol. 66: 45-55.

Burger TD, Shao R, Barker SC. 2013. Phylogenetic analysis of the mitochondrial genomes and nuclear rRNA genes of ticks reveals a deep phylogenetic structure within the genus Haemaphysalis and further elucidates the polyphyly of the genus Amblyomma with respect to Amblyomma sphenodonti and Amblyomma elaphense. Ticks Tick-borne Dis. 4: 265-274.

Burger TD, Shao R, Labruna MB, Barker SC. 2014. Molecular phylogeny of soft ticks (Ixodida: Argasidae) inferred from mitochondrial genomes and nuclear rRNA sequences. Ticks Tick-borne Dis. 5: 195-207.

Camicas JL, Morel PC. 1977. Position systématique et classification des tiques (Acarida: Ixodida). Acarologia 18: 410-420.

Camicas JL, Hervy JP, Adam F, Morel PC. 1998. Les tiques du monde. Nomenclature, stades décrits, hôtes, répartition (Acarida, Ixodida). Orstom, Paris, 233 pp.

Chen Z, Yang X, Bu F, Yang X, Yang X, Liu J. 2010. Ticks (Acari: Ixodoidea: Argasidae, Ixodidae) of China. Exp. Appl. Acarol. 51: 393-404.

Chiappe LM. 1996. Early avian evolution in the southern hemisphere: the fossil record of birds in the Mesozoic of Gondwana. Mem. Queensl. Mus. 39: 533-555.

Chiappe LM. 2009 Downsized dinosaurs: the evolutionary transition to modern birds. Evol. Educ. Out. 2: 248-256.

Chunikhin SP. 1967 Ixodes berlesei Bir. An ixodid tick species new for western Siberia. ZoologicheskyiZhurnal 46: 12561258. In Russian, NAMRU-3 translation 291.

Clarke JA, Tambussi CP, Noriega JI, Ericksson GM, Ketcham RA. 2005. Definitive fossil evidence for the extant avian radiation in the Cretaceous. Nature 433: 305-308.

Clements J, Schulenberg T, Iliff M, Sullivan B, Wood C, Roberson D. 2012. The Ebird/Clements checklist of birds of the world: version 6.7. Available from http://www.birds.cornell.edu/clementschecklist/downloadab le-clements-checklist (Last accession Feb 12, 2016).

Clifford CM, Hoogstraal H. 1965. The occurrence of Ixodes arboricola Schulze and Schlottke (Ixodoidea: Ixodidae) in Africa on northward migrating birds.J. Med. Entomol. 2: 3740.

Clifford CM, Sonenshine DE, Keirans JE, Kohls GM. 1973. Systematics of the subfamily Ixodinae (Acarina: Ixodidae). 1. The subgenera of Ixodes. Ann. Entomol. Soc. Am. 66: 489500 .

Clifford CM, Hoogstraal H, Keirans JE. 1975. The Ixodes ticks (Acarina: Ixodidae) of Nepal. J. Med. Entomol. 12: 115-137.

Close RA, Vickers-Rich P, Trusler P, Chiappe LM, O'Connor J, Rich TH, Kool L, Komarower P. 2009. Earliest Gondwana bird 
from the Cretaceous of southeastern Australia. J. Vert. Paleont. 29: 616-619.

Cooley RA. 1946. The genera Boophilus, Rhipicephalus, and Haemaphysalis (Ixodoidea) of the New World. National Institute of Health Bulletin, (187), $54 \mathrm{pp}$.

Cooley RA, Kohls GM. 1945. The genus Ixodes in North America. National Institute of Health Bulletin. (184), 246 pp.

Cornet, JP. 1995. Contribution à l'étude des tiques (Acarina: Ixodina) de la République Centrafricaine. 4. Inventaire et répartition. Acarologia 36: 203-212.

Cox CB, Moore, PD. 2005. Biogeography. An ecological and evolutionary approach, $7^{\text {th }}$ edition, Blackwell Publishing, Oxford, $428 \mathrm{pp}$.

Dantas-Torres F, Bernardi LF, de Souza-Silva M, Ferreira RL, Onofrio VC, Barros-Battesti DM, Labruna MB. 2009. New records of Ixodes paranaensis (Acari: Ixodidae) from Minas Gerais, southeastern Brazil. Syst. Appl. Acarol. 14: 213-215.

de la Fuente J, Estrada-Peña A, Cabezas-Cruz A, Brey R. 2015. Flying ticks: anciently evolved associations that constitute a risk of infectious disease spread. Parasites \& Vectors 8: 538.

Dietrich M, Gómez-Díaz E, McCoy KD. 2011. Worldwide distribution and diversity of seabirds ticks: implication for the ecology and epidemiology of tick-borne pathogens. Vector Borne Zoonotic Dis. 11: 453-467.

Dietrich M, Kempf F, Boulinier T, McCoy KD. 2014. Tracing the colonization and diversification of the worldwide seabird ectoparasite Ixodes uriae. Mol. Ecol. 23: 3292-3305.

Dobson SJ, Barker SC. 1999. Phylogeny of the hard ticks (Ixodoidea) inferred from 18S rRNA indicates that the genus Aponomma is paraphyletic. Mol. Phyl. Evol. 11: 288-295.

Doby JM. 1998. Contribution à la connaissance de la biologie de Ixodes (Trichotoixodes) pari Leach ( $=1$. frontalis) (Panzer) (Acari: Ixodidae), tique spécifique des oiseaux. Acarologia 39: 315-324.

Dumbleton LJ. 1953. The ticks (Ixodoidea) of the New Zealand subregion. Cape Exped. Ser. Bull. 14: 5-35.

Dumbleton L. 1961. The ticks (Acarina: Ixodoidea) of sea birds in New Zealand waters. New Zealand J. Sci. 4: 760-769.

Dumbleton LJ. 1973. Additions to the New Zealand tick fauna. Tuatara 20: 65-74.

Dunlop JA, Penney D. 2012. Fossil arachnids. Volume 1, Siri Scientific Press, Manchester, $192 \mathrm{pp}$.

Durden LA, Keirans JE. 1996. Nymphs of the genus Ixodes (Acari: Ixodidae) of the United States: taxonomy, identification key, distribution, hosts, and medical/ veterinary importance. Thomas Say Publication in Entomology Monographs (9), 95 pp.

Durden LA, Merker S, Beati L. 2008. The tick fauna of Sulawesi, Indonesia (Acari: Ixodoidea: Argasidae and Ixodidae). Exp. Appl. Acarol. 45: 85-110.

Elbl A, Anastos G. 1966. Ixodid ticks (Acarina, Ixodidae) of Central Africa. Volume IV. Genera Aponomma Neumann, 1899, Boophilus Curtice, 1891, Dermacentor Koch, 1844, Haemaphysalis Koch, 1844, Hyalomma, Koch, 1844 and Rhipicentor Nuttall and Warburton, 1908. Lists and bibliography. Annales du Musée Royal de I 'Afrique Centrale, Série 8, Sciences Zoologique, (148), 412 pp.
Eley TJ. 1977. Ixodes uriae (Acari: Ixodidae) from a river otter. J. Med. Entomol. 13: 5.

Emchuk EM. 1960. Ixodid ticks. 1. External and internal structure, ecology, systematics, distribution and economic importance of ixodid ticks. Fauna Ukrayiny 25: 1-163. In Russian.

Fedorov VG. 1972. Ticks of the superfamily Ixodoidea of birds and their nests in western Siberia. In: Cherepanov, A \& Mater, L.A. (Eds.), Transcontinental associations of migratory birds and their role in distribution of arboviruses. Materialy 5 Simpoziuma po Isucheniyu Roli Pereletnykh Ptits $v$ Rasprostranenii Arbovirusov, Novosibirsk, July 1969, pp. 384388. In Russian, NAMRU-3 translation 1494.

Filippova NA. 1961. Contribution to the taxonomy of ticks of the crenulatus group (Ixodidae, Ixodes, Pholeoixodes). Parazitologicheskiy Sbornik 20: 226-247. [in Russian, English translation by the Translation Unit, Library Branch, Division of Research Services, National Institutes of Health, Bethesda, Maryland]

Filippova NA. 1977. Ixodid tick of subfamily Amblyomminae. Fauna of Russia and neighbouring countries, 4 (5), Nauka Publishing House, St. Petersburg, 436 pp. In Russian.

Fitzgerald EMG, Carrano MT, Holland T, Wagstaff BE, Pickering D, Rich TH, Vickers-Rich P. 2012. First ceratosaurian dinosaur from Australia. Naturwissenschaften 99: 395-405.

Flores FS, Nava S, Batallán G, Tauro LB, Contigiani MS, Díaz LA, Guglielmone AA. 2014. Ticks (Acari: Ixodidae) on wild birds in north-central Argentina. Ticks Tick-borne Dis. 5: 715721.

Furman DP, Loomis EC. 1984. The ticks of California (Acari: Ixodida). Bulletin of the California Insect Survey 25, 1-239.

Gallus S, Janke A, Kumar V, Nilsson MA. 2015. Disentangling the relationship of the Australian marsupial orders using retrotransposon and evolutionary network analyses. Genome Biol. Evol. 7: 985-992.

Gembitsky AS. 1966. On finding Ixodes arboricola P. Sch. and Schl. in birds' nests. Zoologicheskyi Zhurnal 45: 1881-1882. In Russian, NAMRU-3 translation 226.

Gilot B. 1984. Premier inventaire des Ixodidae (Acarina, Ixodoidea) parasites d'oiseaux dans les Alpes françaises et leur avant-pays. Données écologiques sur quelques espèces peu connues. Riv. Parassitol. 1: 303-318.

Gofton AW, Oskam CL, Lo N, Beninati T, Wei H, McCarl V, Murray DC, Paparini A, Greay TL, Holmes AJ, Bunce M, Ryan U, Irwin P. 2015. Inhibition of the endosymbiont "Candidatus Midichloria mitochondrii" during 16S rRNA gene profiling reveals potential pathogens in Ixodes ticks from Australia. Parasites \& Vectors 8: 345

González-Acuña D, Venzal JM, Keirans JE, Robbins RG, Ippi S, Guglielmone AA. 2005. New host and locality records for the Ixodes auritulus (Acari: Ixodidae) species group, with a review of host relationships and distribution in the Neotropical Zoogeographic Region. Exp. Appl. Acarol. 37: 147-156.

González-Acuña, D., Mangold, A.J., Robbins, R.G. \& Guglielmone, A.A. (2009) New host and locality records for the Ixodes auritulus Neumann, 1904 (Acari: Ixodidae) species group in northern Chile. Syst. Appl. Acarol. 14: 47-50.

Gregson JD. 1954. The male of Ixodes signatus Birula (Acarina: Ixodidae). Canad. Entomol. 86: 275-277. 
Gregson JD. 1956. The Ixodoidea of Canada. Canadian Department Agriculture Science Service Entomological Division Publication, (930), 92 pp.

Grimaldi, D.A., Engel. M.S. \& Nascimbene, P.C. (2002) Fossiliferous cretaceous amber from Myanmar (Burma): its rediscovery, biotic diversity, and paleontological significance. American Museum Novitates (3361), 71 pp.

Guglielmone AA, Nava S. 2014. Names for Ixodidae (Acari: Ixodoidea): valid, synonyms, incertae sedis, nomina dubia, nomina nuda, lapsus, incorrect and suppressed names-with notes on confusions and misidentifications. Zootaxa 3767: 1256.

Guglielmone AA, Venzal JM, González-Acuña D, Nava S, Mangold AJ. 2006. The phylogenetic position of Ixodes stilesi Neumann, 1911 (Acari: Ixodidae): morphological and preliminary molecular evidences from 16S rDNA sequences. Syst. Parasitol. 65: 1-11.

Guglielmone AA, Robbins RG, Apanaskevich DA, Petney TN, Estrada-Peña A, Horak IG. 2014 The hard ticks of the world (Acari: Ixodida: Ixodidae). Springer, Dordrecht, Heidelberg, New York, London, 738 pp.

Guiguen C, Monnat JY, Launay H, Beaucournu JC. 1987 Ectoparasites des oiseaux en Bretagne. III. Ixodoidea. Cahiers de l'Office de la Recherche Scientifique et Technique Outremer, Série Entomologie Medicale et Parasitologie (special issue), 73-81.

Heath ACG. 2006. Observations on Ixodes eudyptidis Maskell (Acari: Ixodidae), Ornithodoros capensis Neumann (Acari: Argasidae), and other tick parasites of sea birds of New Zealand. Syst. Appl. Acarol. 11: 131-140.

Heath ACG. 2010. A review of ectoparasites of Apteryx spp. (kiwi) in New Zealand, with new host records, and the biology of Ixodes anatis (Acari: Ixodidae). Tuhinga: 21, 147-159

Heath ACG, Cane RP. 2010. A new species of Ixodiphagus (Hymenoptera: Chalcidoidea: Encyrtidae) parasitizing seabird ticks in New Zealand. New Zealand J. Zool. 37: 147-155.

Heath ACG, Palma RL, Cane RP, Hardwick S. 2011. Checklist of New Zealand ticks (Acari: Ixodidae, Argasidae). Zootaxa 2995: 55-63.

Hoogstraal H. 1967. Ixodes jacksoni n. sp. (Ixodoidea: Ixodidae), a nest parasite of the spotted cormorant, Phalacrocorax punctatus (Sparrman), in New Zealand. J. Med. Entomol. 4: 37-41.

Hoogstraal H. 1978. Biology of ticks. In: Wilde JKH (Ed.), Tickborne diseases and their vectors. University of Edinburgh, Centrefor Tropical Veterinary Medicine Edinburgh, pp. 3-14

Hoogstraal H, Aeschlimann A. 1982. Tick-host specificity. Bull. Soc. Entomol. Suisse 55: 5-32.

Hoogstraal H, Kim KC. 1985. Tick and mammal coevolution, with emphasis on Haemaphysalis. In: Kim KC. (Ed.), Coevolution of parasitic arthropods and mammals. John Wiley \& Sons, New York and other cities, pp. 505-568.

Hoogstraal H, Wassef HY. 1973. The Haemaphysalis ticks (Ixodoidea: Ixodidae) of birds. 3. H. (Ornithophysalis) subgen. n.: definition, species, hosts and distribution in the Oriental, Palearctic, Malagasy, and Ethiopian Faunal Regions. J. Parasitol. 59: 1099-1117.

Hoogstraal H, Lim BL, Nadchatram M, Anastos G. 1972. The Gunong Benom Expedition 1967. 8. Ticks (Ixodidae) of Gunong Benom and their altitudinal distribution, hosts and medical relationships. Bull. Br. Mus. Nat. Hist. Zool. 23: 167186.

Hoogstraal H, Wassef HY, Converse JD, Keirans JE, Clifford CM, Feare, CJ. 1976. Amblyomma loculosum (Ixodoidea: Ixodidae): identity, marine bird and human hosts, virus infection, and distribution in the southern Oceans. Ann. Entomol. Soc. Am. 69: 3-14.

Horak IG, Spickett AM, Braack LEO, Penzhorn BL, Bagnall RJ, Uys AC. 1995. Parasites of domestic and wild animals in South Africa. XXXIII. Ixodid ticks on scrub hares in the north-eastern regions of Northern Transvaal and of KwaZulu-Natal. Onderstepoort J. Vert. Res. 62: 123-131.

Hornok S, Görföl T, Estók P, Tu VT, Kontschán J. 2016. Description of a new tick species, Ixodes collaris n. sp. (Acari: Ixodidae), from bats (Chiroptera: Hipposideridae, Rhinolophidae) in Vietnam. Parasites \& Vectors 9: 332.

Jaenson TGT, Jensen JK. 2007. Records of ticks (Acari, Ixodidae) from the Faroe Islands. Norwegian J. Entomol. 54: 11-15.

Jaenson TGT, Talleklint L, Lundqvist L, Olsen B, Chirico J, Mejlon H. 1994. Geographical distribution, host associations, and vector roles of ticks (Acari: Ixodidae, Argasidae) in Sweden. J. Med. Entomol. 31: 240-256.

Jeyaprakash A, Hoy MA. 2009. First divergence time estimates of spiders, scorpions, mites and ticks (subphylum: Chelicerata) inferred from mithochondrial phylogeny. Exp. Appl. Acarol. 47: 1-18.

Kang JG, Kim HC, Choi CY, Nam HY, Chae HY, Chong ST, Klein TA, Ko S, Chae JS. 2013. Molecular detection of Anaplasma, Bartonella, and Borrelia species in ticks collected from migratory birds from Hong-do Island, Republic of Korea. Vector Borne Zoonotic Dis. 13: 215-225.

Karg W, Schorlemmer A. 2008. Origin and classification of the Ixodides (ticks) within the Parasitiformes Reuter, 1909 (Acarina). Acarologia 48: 123-134.

Karg W, Schorlemmer A. 2013. Origin of five unique mitegenera in geological periods compared to other groups of Gamasina (Acarina, Parasitiformes) and description of two new species of Rykellus Lee and Oloopticus Karg. Zoosyst. Evol. 89: 193-207.

Keirans JE. 1967. Some avian ectoparasites in New England. Entomol. News 78: 40-42.

Keirans JE. 1985 George Henry Falkiner Nuttall and the Nuttall tick catalogue. United States Department of Agriculture, Agricultural Research Service Miscelaneous Publication, (1438), 1785 pp.

Keirans JE, Klompen JSH. 1996. Amblyomma quadricavum (Schulze) (new combination), and Amblyomma arianae Keirans and Garris, a new junior synonym of Amblyomma quadricavum (Acari: Ixodidae). Proc. Entomol. Soc. Wash. 98: 164-165.

Keirans JE, Durden LA, Hopla CE. 1993. Description of immature stages of Ixodes (Pholeoixodes) baergi (Acari: Ixodidae), a parasite of cliff swallows in the United States. J. Med. Entomol. 30: 735-739.

Keirans JE, Hutcheson HJ, Durden LA, Klompen JSH. 1996. Ixodes (Ixodes) scapularis (Acari: Ixodidae): redescription of all active stages, distribution, hosts, geographical variation, and medical and veterinary importance. J. Med. Entomol. 33: 297-318. 
Kim HC, Ko S, Choi CY, Nam HY, Chae HY, Chong ST, Klein TA, Sames WJ, Robbins RG, Chae JS. 2009. Migratory bird tick surveillance, including a new record of Haemaphysalis ornithophila Hoogstraal and Kohls 1959 (Acari: Ixodidae) from Hong-do (Hong Island), Republic of Korea. Syst. Appl. Acarol. 14: $3-10$

Klompen JSH. 1999. Phylogenetic relationships in the family Ixodidae with emphasis on the genus Ixodes (Parasitiformes: Ixodidae). In: Needham GR, Horne DJ, Welbourn WC. (Eds.), IX Proceedings of the International Congress of Acarology, Ohio State University, Columbus, pp. 349-353.

Klompen JSH, Oliver JH, Keirans JE, Homsher PJ. 1997. A reevaluation of relationships in the Metastriata (Acari: Parasitiformes: Ixodidae). Syst. Parasitol. 38: 1-24.

Klompen JSH, Black WC, Keirans JE, Norris DE. 2000. Systematic and biogeography of hard ticks, a total evidence approach. Cladistics 16: 79-102.

Kohls GM, Clifford CM. 1967. The male and larva of Ixodes laysanensis Wilson with notes on rearing (Acarina, Ixodidae). J. Med. Entomol. 4: 83-86.

Kohls GM, Ryckman RE. 1962. New distributional records of ticks associated with cliff swallows, Petrochelidon spp., in the United States. J. Parasitol. 48: 507-508.

Kolonin GV. 2008. Birds as hosts of ixodid ticks (Acarina: Ixodidae). Entomol. Rev. 88: 1012-1015.

Kozlovskaya OL, Chernykh PA, Koshkin SM. 1968. New and little known ectoparasite species in Khabarovsk region. Izvestiya Irkutskogo Gosudarstvennogo NauchoIssledovatel'skogo. Protivochumnogo Instituta i Sibiri Dal'nego Vostoka 27: 312-315. In Russian.

Lindquist EE. 1984. Current theories on the evolution of major groups of Acari and on their relationships with other groups of Arachnida with consequent implications for their classification. In: Griffiths DA, Bowman CE (eds.), Acarology $\mathrm{VI}$, volume 1, John Wiley \& Sons, New York, pp. 28-62

Lugarini $C$, Martins TF, Ogrzewalska $M$, Vasconcelos NCT, Ellis VA, Oliveira JB, Pinter A, Labruna MB, Silva JCR. 2015. Rickettsial agentes in avian ixodid ticks in northeast Brazil. Ticks Tick-borne Dis. 6: 364-375.

Luz HR, Faccini JLH, Landulfo GA, Berto BP. 2016. New host record of ticks (Ixodidae) infesting birds in an Atlantic Forest fragment in southeastern Brazil. Syst. Appl. Acarol. 21: 11071115.

Mans BJ, de Klerk D, Pienaar R, Latif A. 2011. Nutalliella namaqua: a living fossil and closest relative to the ancestral tick lineage: implications for the evolution of bood feeding ticks. PLOS ONE 6: e23675.

Mans BJ, Klerk D, Pienaar R, Castro MH, Latif AA. 2012. The mitochondrial genomes of Nuttalliella namaqua (Ixodoidea: Nuttalliellidae) and Argas africolumbae (Ixodoidea: Argasidae): estimation of divergence dates for the major tick lineages and reconstruction of ancestral blood-feeding characteristics. PLOS ONE 7: e4946.

Mans BJ, de Klerk D, Pienaar R, Latif A. 2014.The host preferences of Nuttalliella namaqua (Ixodoidea: Nuttalliellidae): a generalist approach to surviving multiple host-switches. Exp. Appl. Acarol. 62: 233-240.

Mans BJ, Klerk D, Pienaar R, Castro MH, Latif AA. 2015. Nextgeneration sequencing as means to retrieve tick systematic markers, with the focus on Nuttalliella namaqua (Ixodoidea: Nuttalliellidae). Ticks Tick-borne Dis. 6: 450-462.

Mans BJ, Castro MH, Pienaar R, Klerk D, Gaven P, Genu S, Latif AA. 2016. Ancestral reconstruction of tick lineages. Ticks Tick-borne Dis. 7: 509-535.

Martin AJ, Vickers-Rich P, Rich TH, Hall M. 2014. Oldest known avian footprints from Australia: Eumeralia formation (Albian), dinosaur cove, Victoria. Paleontology 57: 7-19.

Martyn KP. 1988. Provisional atlas of the ticks (Ixodoidea) of the British Isles. Biological Records Centre, Natural Environment Research Council, UK, 62 pp.

Matthysse JG, Colbo MH. 1987. The ixodid ticks of Uganda. Entomological Society of America, College, Park, Maryland, $426 \mathrm{pp}$.

Maturano, R, Faccini JLH, Daemon E, Fazza POC, Bastos RR. 2015. Additional information about ticks parasitism in Passeriformes birds in an Atlantic Forest in southeastern Brazil. Parasitol. Res. 114: 4181-4193.

Mitchell KJ, Pratt RC, Watson LN, Gibb GC, Llamas B, Kasper M, Edson J, Hopwood B, Male D, Armstrong KN, Meyer M, Hofreiter M, Austin J, Donnellan SC, Lee MSY, Phillips MJ, Cooper A. 2014. Molecular phylogeny, biogeography, and habitat preference evolution of marsupials. Mol. Biol. Evol. 31: $2322-2330$

Miyamoto K, Masuzawa T, Kudeken M. 2000. Tick collection from wild birds and detection of Lyme disease spirochetes from a new avian reservoir in Japan. Med. Entomol. Zool. 51: 221-226.

Monerris M, Paredes-Esquivel C, Miranda MA. 2011. New records of tick fauna from the Balearic Islands (Spain) (Acari: Ixodidae). Bol. Soc. Esp. Entomol. 35: 477-481.

Morel PC. 1969. Contribution a la connaissance de la distributuion des tiques (Acariens, Ixodidae et Amblyommidae) en Afrique ethiopienne continentale. These de Doctorat en Sciences Naturelles. Université de París, 398 pp.

Mullen G, Anderson R, Nolan P. 1999. Tick paralysis in wild birds: a cyclic phenomenon? High. Agric. Res. 46: 19-20.

Muñoz-Leal S, González-Acuña D. 2015. The tick Ixodes uriae (Acari: Ixodidae): hosts, geographical distribution, and vector roles. Ticks Tick-borne Dis. 6: 843-868.

Muñoz-Leal S, Tarragona EL, Martins TF, Martín CM, BurgosGallardo F, Nava S, Labruna MB, González-Acuña D. 2016. Liolaeums lizards (Squamata: Liolaemidae) as hosts for the nymph of Amblyomma parvitarsum (Acari: Ixodidae), with notes on Rickettsia infection. Exp. Appl. Acarol. 70: 253-259.

Musser AM. 2003. Review of the monotreme fossil record and comparison of paleontological and molecular data. Comp. Biochem. Phys. Part A 136: 927-942.

Nava S, Venzal JM, González-Acuña D, Martins TF, Guglielmone AA. 2017. Ticks of the Southern Cone of America: Diagnosis, distribution and hosts with taxonomy, ecology and sanitary importance. Elsevier, Academic Press, London, $352 \mathrm{pp}$

Norris DE, Klompen JSH, Black WC. 1999. Comparison of the mithochondrial $12 \mathrm{~S}$ and $16 \mathrm{~S}$ ribosomal DNA genes in resolving phylogenetic relationships among hard ticks. Ann. Entomol. Soc. Am. 92: 117-129. 
Norte AC, Silva LP, Tenreiro PJQ, Felgueiras MS, Araújo PM, Lopes PB, Mato, C, Rosa A, Ferreira PJSG, Encarnação P, Rocha A, Escudero R., Anda P, Núncio MS, Carvalho L. 2015. Patterns of tick infestation and their Borrelia burgdorferi s.l. infection in wild birds in Portugal. Ticks and Tick-borne Dis. 6: $743-750$

Oliver JH. 1989. Biology and systematics of ticks (Acari: Ixodida). Ann. Rev. Ecol. Syst. 20: 397-430.

Pacheco MA, Battistuzzi FU, Lentino M, Aguilar RF, Kumar S, Escalante AA. 2011. Evolution of modern birds revealed by mitogenomics: timing the radiation and origin of major orders. Mol. Bioel. Evol. 28: 1927-1942

Papadopoulos B, Humair PF, Aeschlimann A, Vaucher C, Büttiker W. 2001. Ticks on birds in Switzerland. Acarologia: 42: 3-19.

Parola P, Cornet JP, Sanogo YO, Miller RS, Thien HV, González JP, Raoult D, Telford SR, Wongsrichanalai C. 2003. Detection of Ehrlichia spp., Anaplasma spp.,Rickettsia spp., and other eubacteria in ticks from the Thai-Myanmar border and Vietnam. J. Clin. Microbiol. 41: 1600-1608.

Petney TN, Keirans JE. 1994. Ticks of the genus Ixodes in South-east Asia. Trop. Biomed. 11: 123-134.

Prokop'ev VN, Stupina AG, Emel'yanova ND. 1979. Certain results and prospects of studying parasitic ticks and mites in Buryat ASSR. Trudy Parazity Zhivotnykh i Vrediteli Rasteni Pribaikal'ya Zabaikal'ya, Ulan-ude, pp. 94-102. In Russian, NAMRU-3 translation 1741.

Rajagopalan PK. 1963. Haemaphysalis megalaimae sp. n., a new tick from the small green barbet (Megalaima viridis) in India. J. Parasitol. 49: 340-345.

Rajagopalan PK. 1972 Ixodid ticks (Acarina: Ixodidae) parasitizing wild birds in the Kyasanur Forest disease area of Shimoga District, Mysore State, India. J. Bombay Nat. Hist. Soc. 69 : $55-78$

Rajagopalan PK, Patil AP, Boshell J. 1968. Ixodid ticks on their mammalian hosts in the Kyasanur Forest disease area of Mysore State, India, 1961-1964. Indian J. Med. Res. 56: 510526.

Ramos DGS, Melo ALT, Martins TF, Alves AS, Pacheco TA, Pinto LB, Pinho JB, Labruna MB, Dutra V, Aguiar DM, Pacheco RC. 2015. Rickettsial infection in ticks from wild birds from Cerrado and Pantanal region of Mato Grosso, Midwestern, Brazil. Ticks Tick-borne Dis. 6: 836-842.

Ramos JA, Bowler J, Davis I, Venis S, Quinn J, Middleton C. 2002. A different developmental pattern of the seabird tick Amblyomma loculosum when lizards are present. Acarologia 42: $215-222$

Rao, T.R., Dhanda, V., Bhat, H.R. \& Kulkarni, S.M. (1973) A survey of haematophagous arthropods in Western Himalayas, Sikkim and Hill Districts of West Bengal. A general account. Indian J. Med. Res. 61: 1421-1461.

Roberts FHS. 1960. A systematic study of the Australian species of the genus Ixodes (Acarina: Ixodidae). Aust. J. Zool. 8: 392-485.

Roberts FHS. 1964. The tick fauna of Tasmania. Records of Queen Victoria Museum Launceston, New Series (17), 2-8.

Roberts FHS. 1970. Australian ticks. CSIRO, Melbourne, 267 pp.
Santos Dias. JAT. 1958. Notes on various ticks (Acarina Ixodidae) in collection at some entomological institutes in Paris and London. An. Inst. Med. Trop. 15: 459-563.

Schulze P. 1937. Trilobita, Xiphosura, Acarina. Eine morphologische Untersuchung Über Plangleichheit zwischen Trilobiten und Spinnentieren. Z. Morphol. Okol. Tiere 32: 181-226.

Schwan TG, Kelly PR. 1981. Ixodes signatus (Ixodoidea: Ixodidae) parasitizing pigeon guillemots on the Channel Islands, California. J. Med. Entomol. 18: 171-172.

Scott JD, Durden LA. 2015. First record of Amblyomma rotundatum tick (Acari: Ixodidae) parasitizing a bird collected in Canada. Syst. Appl. Acarol. 20: 155-161.

Scott JD, Anderson JF, Durden LA. 2012. Widespread dispersal of Borrelia burgdorferi- infected ticks collected from songbirds across Canada. J. Parasitol. 98: 49-59.

Sixl W. Nosek J. 1972. Zur medizinischen Bedeutung der Zecken Österreichs. Mitt. Abt. Zool. Landesmus 1: 29-50.

Sonenshine DE, Stout IJ. 1970. A contribution to the ecology of ticks infesting wild birds and rabbits in the Virginia-North Carolina piedmont (Acarina: Ixodidae). J. Med. Entomol. 7: 645-654.

Stothard DS, Fuerst PA. 1995 Evolutionary analysis of the spotted fever and typhus groups of Rickettsia using 16S rRNA gene sequences. Syst. Appl. Microbiol. 18: 52-61.

Swift RJ, Heath ACG, Jamieson SE. 2015. The kiwi tick, Ixodes anatis Chilton, 1904 (Acari: Ixodidae): aspects of its biology and ecology. Syst. Appl. Acarol. 20: 1-12.

Takano A, Fujita H, Kadosaka T, Takahashi M, Yamauchi T, Ishiguro F, Takada N, Yano Y, Oikawa Y, Honda T, Gokuden M, Tsunoda T, Tsurumi M, Ando S, Andoh M, Sato K, Kawabata H. 2014. Construction of a DNA database for ticks collected in Japan: application of molecular identification based on the mithocondrial 16S rDNA gene. Med. Entomol. Zool. 65: 13-21.

Tanskul P, Stark HE, Inlao I. 1983. A checklist of ticks of Thailand (Acari: Metastigmata: Ixodoidea). J. Med. Entomol. 20: 330-341.

Theiler G. 1962. The Ixodoidea parasites of vertebrates in Africa south of the Sahara (Ethiopian region). Report to the Director of Veterinary Services, Onderstepoort, South Africa, Project S.9958, $260 \mathrm{pp}$

Tolesano-Pascoli G, Garcia FI, Gomes CRG, Diniz KC, Onofrio VC, Venzal JM, Szabó JMP. 2014. Ticks (Acari: Ixodidae) on swifts (Apodiformes: Apodidae) in Minas Gerais, Brazil. Exp. Appl. Acarol. 64: 259-263.

Tovornik D. 1991. Data on ticks Ixodes frontalis (Panzer, 1798) and Ixodes arboricola Schulze et Schlottke, 1929 found on birds in Yugoslavia. Biol. Vĕst. 39: 157- 164.

Trapido H, Goverdhan MK, Rajagopalan PK, Rebello MJ. 1964. Ticks ectoparasitic on monkeys in the Kyasanur Forest disease area of Shimoga District, Mysore State, India. A. J. Trop. Med. Hyg. 13: 763-772.

Trilar T. 2004. Ticks (Acarina: Ixodidae) on birds in Slovenia. Acrocephalus 25: 213-216.

Ulmanen I, Saikku P, Vikberg P, Sorjonen J. 1977. Ixodes lividus (Acari) in sand martin colonies in Fennoscandia. Oikos 28: 20-26. 
van Rheede T, Bastiaans T, Boone DN, Hedges SB, de Jong WW, Madsen O. 2006. The platypus is in its place: nuclear genes and indels confirm the sister group relation of monotremes and therians. Mol. Biol. Evol. 23: 587-597.

Voltzit OV. 1997. New faunistic records of the ixodid ticks from eastern regions of Russia in collections of the Zoological Museum of the Moscow State University. Description of the nymph of Ixodes (Monoixodes) maslovi. Parazitologiya 31: 265-268. In Russian.

Walker ED, Stobierski MG, Poplar ML, Smith TW, Murphy AJ, Smith PC, Schmitt SM, Cooley TM, Kramer CM. 1998. Geographic distribution of ticks (Acari: Ixodidae) in Michigan, with emphasis on Ixodes scapularis and Borrelia burgdorferi. J. Med. Entomol. 35: 872-882.

Walter DE, Proctor HC. 2013. Mites: ecology, evolution \& behviour. $2^{\text {nd }}$ edition, Springer Science + Business Media, Dordrecht, $494 \mathrm{pp}$.

Webb JP, Bennett SG, Challet GL. 1990. The larval ticks of the genus Ixodes Latreille (Acari: Ixodidae) of California. Bull. Soc. Vect. Ecol. 15: 73-124.

Williams DC, Wills W, Durden L.A, Gray EW. 1999. Ticks of South Carolina (Acari: Ixodoidea). J. Vect. Ecol. 24: 224-232.

Wilson N. 1964a. Ixodes laysanensis, a new species of tick from birds on Laysan island (Metastigmata: Ixodidae). J. Med. Entomol. 1: 165-168.

Wilson N. 1964b. Description of male, nymph and larva and redescription of female of Ixodes collocaliae Schulze. Pacific Insects 6: 300-308.

Wilson N 1970a. New distributional records of ticks from Southeast Asia and the Pacific (Metastigmata: Argasidae, Ixodidae). Orient Insects 4: 37-46.

Wilson N. 1970b. Acarina: Metastigmata: Ixodidae of South Georgia, Heard and Kerguelen. Pacific Insects Monographs 23: 78-88.

Wilson N, Kale HW. 1972. Ticks collected from Indian River County, Florida (Acari: Metastigmata: Ixodidae). Florida Entomol. 55: 53-57.

Xu R, Li K. 1997. A collection of ticks from Guizhou, China. Syst. Appl. Acarol. 2: 245-246. Yamaguti N, Tipton VJ, Keegan HL, Toshioka S. 1971. Ticks of Japan, Korea, and the Ryukyu Islands. Brigham Young University, Science Bulletin, Biological Series, 15 (1), 226 pp.

Yamauchi T. 2001. A bibliographical survey of host-parasite relationships between birds and ticks from Japan. Bull. Hoshizaki Green Found. 5: 271-308. In Japanese.

Yamaguti N, Tipton VJ, Keegan HL, Toshioka S. 1971. Ticks of Japan, Korea, and the Ryukyu Islands. Brigham Young University, Science Bulletin, Biological Series, 15 (1), 226 pp.

Yu X, Yr RY, Gong ZD. 1997. The tick fauna of Xinjiang. Xinjiang Scientific, Technological and Medical Publishing House, Urumqi, China, 168 pp. In Chinese.

Zumpt F. 1951 Phylogenie der Zecken und "Natürliches System“. Z. Parasitenkd. 15: 87-101.

Zumpt F. 1952. The ticks of sea birds. Australian National Antarctic Research Expedition Reports, Series B, Volume 1, Zoology, pp. 12-20. 